\title{
A Post-Environmental Discourse: Rhetoric, Science and Legitimacy in Environmental News Coverage of Lake Winnipeg, Canada
}

\author{
By
}

Garrity Hill

A thesis submitted to the Victoria University of Wellington in fulfilment of the requirements for the degree of Master of Arts in Sociology

Victoria University of Wellington

2012 



\begin{abstract}
In post-environmental news discourse, environmentalism is reduced to a rhetorical motif that is relayed by all sides of the political debate, including the environmental opposition. The phase of post-environmentalism in environmental discourse is indicated by the absorption of environmental messages into mainstream discourse so that they are no longer 'owned' by subversive environmentalists, but by anyone claiming to represent the cause. The result is that a counter-discourse is no longer present in the discussion to challenge dominant assumptions about unlimited economic growth. Using critical discourse analysis, this thesis examines the news coverage of governmental regulations aimed at reducing toxic algae in Lake Winnipeg, Canada. The thesis describes how the science is used in the narratives, and compares patterns of doubting science in the coverage with similar patterns found in news discourse historically. The analysis shows that the pro-lake cause is recruited throughout the coverage to boost legitimacy for the Manitoba hog industry and the City of Winnipeg, who leveraged public campaigns opposing the regulations. Rather than contributing to a public understanding of the tension between environmental and economic paradigms, the simplistic cost-benefit analysis of the regulations in the coverage decontextualises the problem from its complex politicaleconomic origins. Furthermore, rather than presenting environmental science in a way that aids public understanding, science is either credited or discredited to reinforce the industry and governmental positions. The need for transparent communication of environmental problems and their causes is thus hindered by the legitimacy claims-making that dominates the discourse. The repeated and shared voicing of environmental messages in the media further embeds the discourse into a post-environmental phase by excluding a counter-discourse from the discussion environmentalism becomes talked about by everyone, and yet discussed by no one.
\end{abstract}




\section{Acknowledgements}

Many thanks go to my supervisors Trish Nickel and Carol Harrington. Trish thank you for your insight, humour, and insistence that I should 'just write through' my mini-crises. Carol - thank you for taking over as my supervisor during these last crucial months. Your detailed feedback was so helpful, and your patience amazed me as I missed just about every deadline we set!

Thank you to my editors: Kellie Hoy, Jared Walton, Sonja Bohn, Alan Bowd, Kent Lambert and Vanessa Bowden. The time you took to give your feedback was much appreciated.

I thank my old and new friends Kent Lambert, Sarah Gibb, Liz Novak, Kellie Hoy, Sonja Bohn and Jared Walton. You brilliant, generous people seemed to come into my life exactly when I needed your encouragement, laughs, inspiration and rides home. Thank you.

I will forever be a 'child of the lake', thanks to all the colourful seasons I have spent with my family at our cottage on gorgeous Lake Winnipeg. Mom and Dad, thank you. This is for you both.

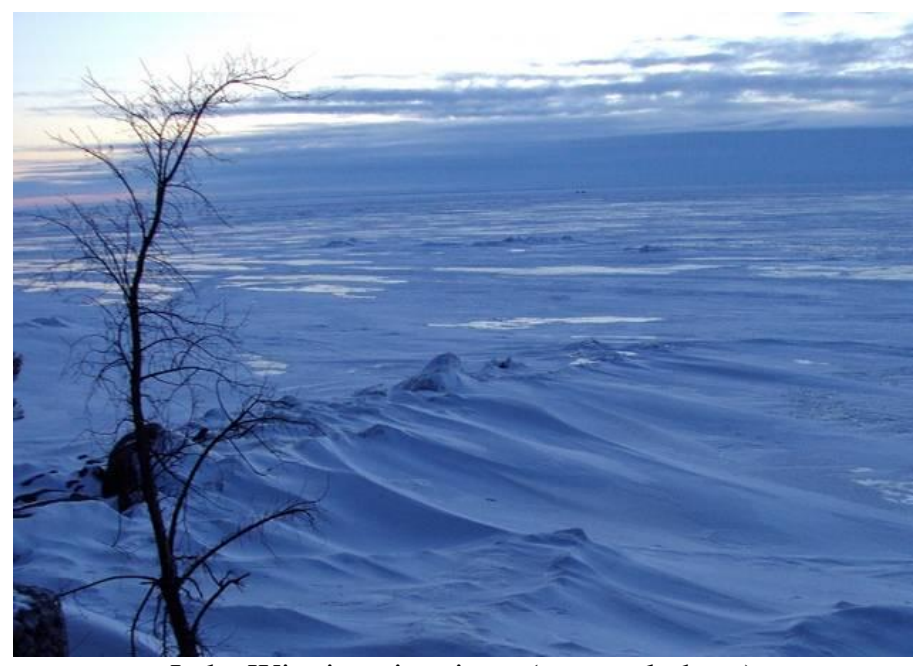

Lake Winnipeg in winter (personal photo) 


\section{Table of contents}

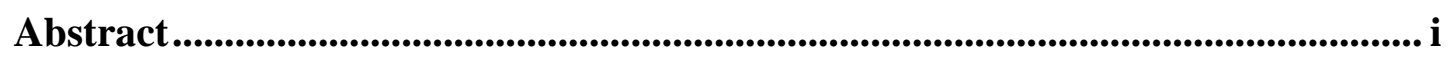

Acknowledgements.................................................................................................. ii

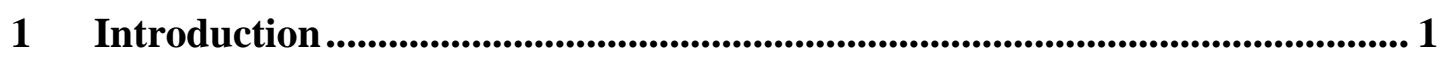

1.1 Toxic algae in Lake Winnipeg .......................................................... 1

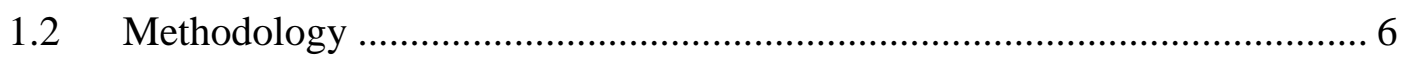

2 Environmental News Discourse in a Public-Sphere-Turned-Marketplace 11

2.1 The environmental/economic paradigmatic tension................................ 11

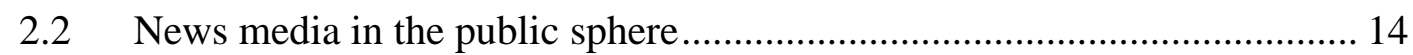

2.3 News media micro-processes and environmental reporting....................... 16

2.4 The media political economy and legitimacy claims-making ................... 20

2.5 Rhetoric and framing to aid legitimacy claims-making ........................... 26

2.6 Manufacturing uncertainty of environmental science ............................... 28

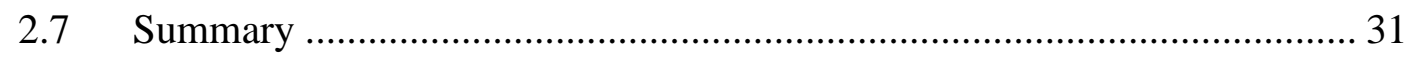

3 Findings and Analysis: Two Narrative Frames, Two Legitimacy Claims.. 34

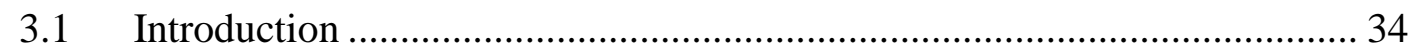

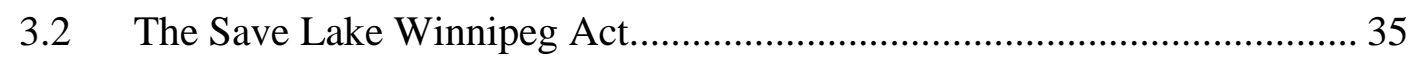

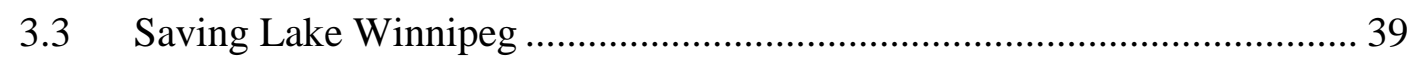

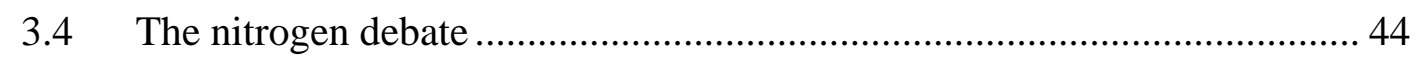

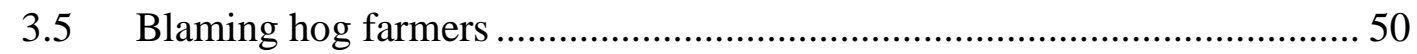

3.6 Adding context to the blaming hog farmers narrative frame .................... 67

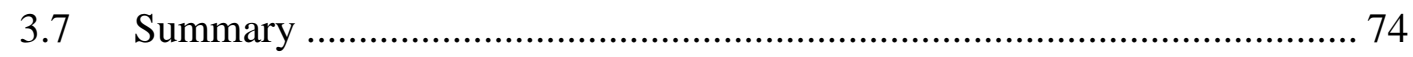

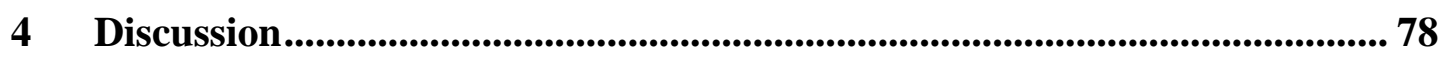

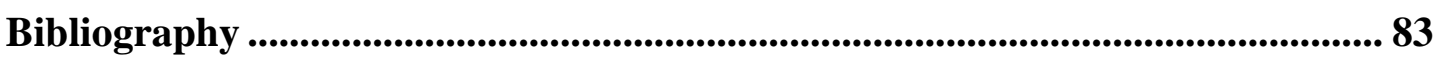

Appendix I: List of News Articles......................................................................... 94

Appendix II: “Saving Lake Winnipeg: A Letter of Concern” Advertisement... 98 



\section{Introduction}

\subsection{Toxic algae in Lake Winnipeg}

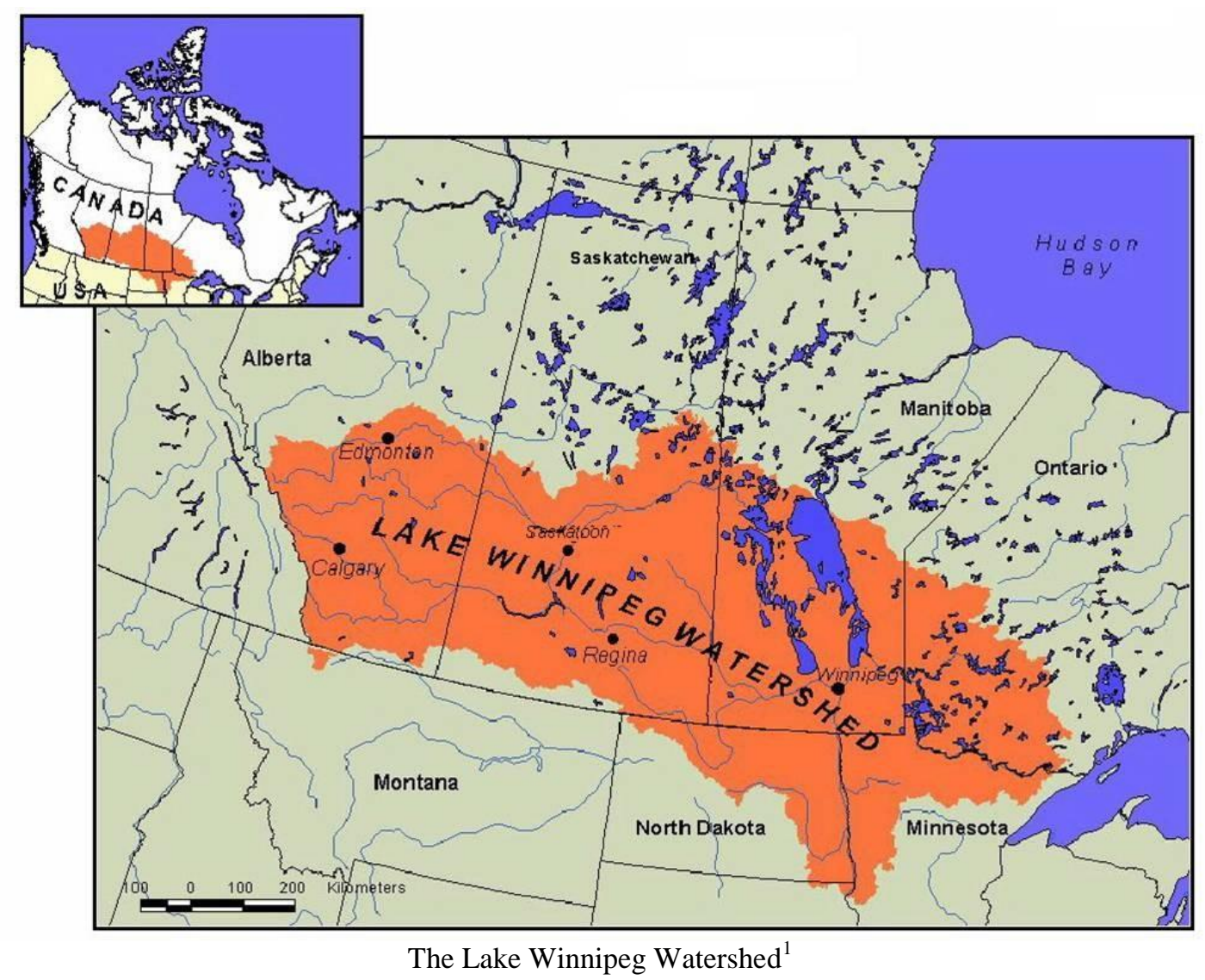

All water is connected. All the rain, snow, ice, groundwater, streams, rivers, wetlands, lakes and oceans on earth are connected through a global water cycle of continuous movement. The rain and snow that land on the predominantly flat prairies and forests of the Lake Winnipeg Watershed, in the centre of North America, run into rivers that flow into Lake Winnipeg, before eventually flowing out again into Hudson Bay via the Hudson River, uniting with the world's oceans. With the largest watershed-to-lake ratio in the world, the Lake Winnipeg Watershed is 40 times larger than the lake itself (Lake Winnipeg Implementation Committee (LWIC), 2005: 3). The Lake Winnipeg Watershed is approximately one million

\footnotetext{
${ }^{1}$ http://www.lakewinnipeg.org/web/index.shtml
} 
square kilometers in area, is home to six million people, and spans four Canadian provinces (Alberta, Saskatchewan, Manitoba and Ontario) together with four American states (Montana, North Dakota, South Dakota and Minnesota) (Environment Canada (EC), 2001: 1). Lake Winnipeg itself is the sixth largest lake in Canada and the tenth largest freshwater lake in the world - it is nearly 24,000 square kilometers in area and 436 kilometers in length from north to south (EC, 2011: 2). The lake supports a population of 23,000 in small communities around its shores, many of which depend on the lake as a source of drinking water (LWIC, 2005: 5). The lake also hosts around 10,000 cottages for seasonal residents (LWIC, 2005:17). A problem with a lake as big as Lake Winnipeg is a big problem and certainly not an isolated one. There is no such thing as an isolated problem when it comes to water.

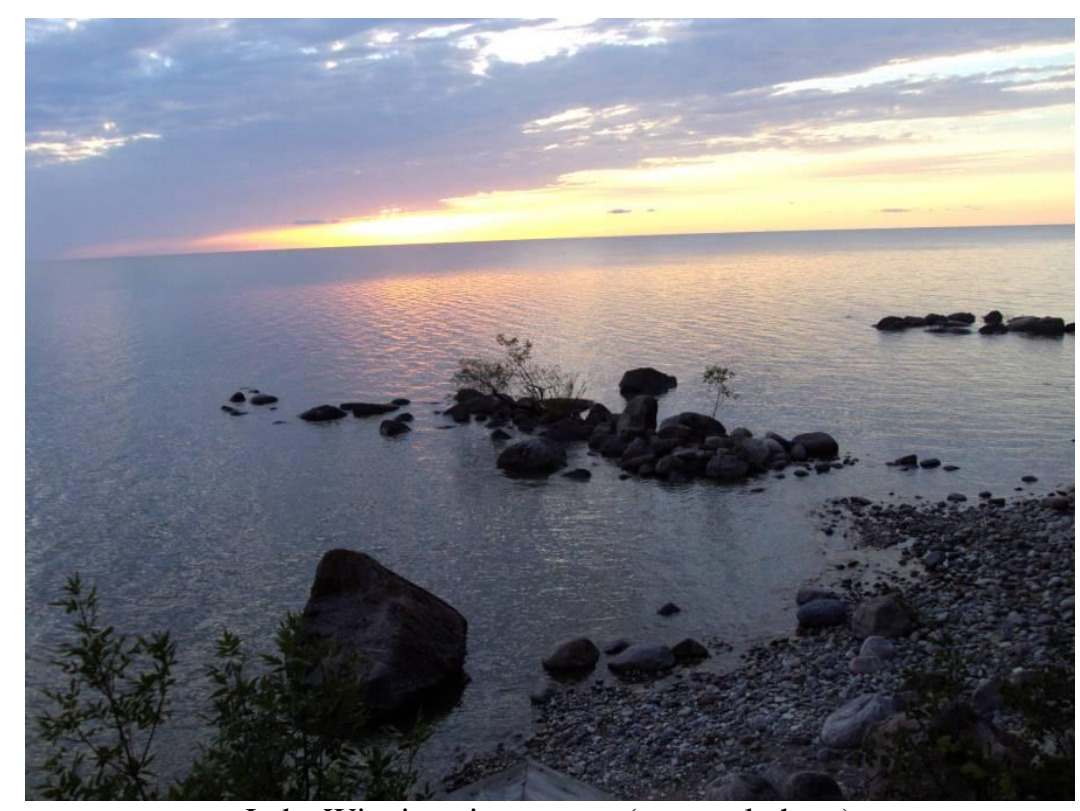

Lake Winnipeg in summer (personal photo)

In the last decade, there have been noticeable changes to the health of Lake Winnipeg. There has been an increase in algal blooms on the lake in the summer months, and a shift toward more cyanobacteria blooms, such as blue-green algae, which can produce toxins that can cause harm to humans and other animals (EC, 2011: 11; LWIC, 2005: 3). While some forms of algae are naturally found on Lake Winnipeg, algal blooms have increased 300 to 500 per cent in the last century (EC, 2011: 11). EC reported that the levels of algal toxins in Lake Winnipeg are usually low enough to meet drinking water and recreational quality guidelines; although in 
recent years, the toxins have "occasionally" reached hazardous quantities for recreational users (2011: 11).

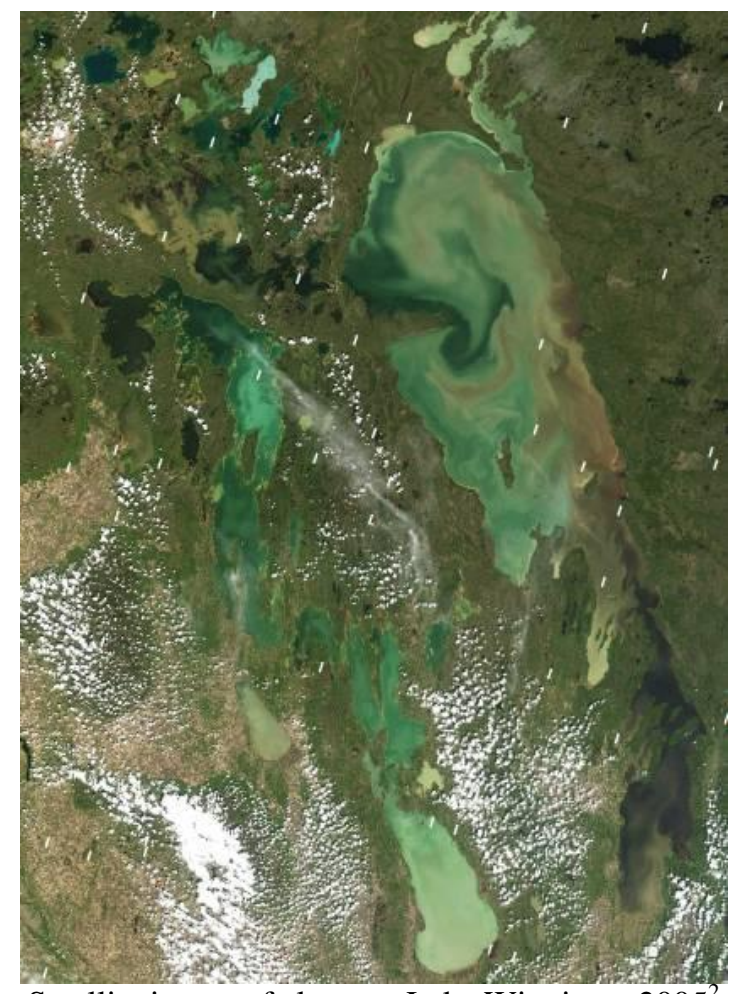

Satellite image of algae on Lake Winnipeg, $2005^{2}$

Lake Winnipeg's algae started receiving local media attention in the early 2000s. By 2005, Lake Winnipeg reached Canada-wide news when images of the algae were shown to be visible from satellite cameras. This was the worst year for algae that the lake had seen; at one point in the summer of 2005 , algae covered up to 14,000 square kilometers - more than half of the lake's surface (LWIC 2005: 23). The nation started to find cause for alarm at the idea of algae, one of the smallest forms of life, being so pervasive that it could be seen from space. By 2009 Macleans, a Canadian national magazine, declared Lake Winnipeg "Canada's sickest lake" (Macdonald, 2009).

Due to the rising media attention, Manitobans started to wonder what was causing the algae outbreaks. They looked to science for answers, but the lake had been under-studied up to this point, compared to other lakes in Canada (LWIC, 2005). Through government-funded research projects, scientists started to gather ecological

2 http://home.cc.umanitoba.ca/ gmccullo/LW sat2005.htm 
information about the Lake Winnipeg Watershed and determined that the levels of phosphorus and nitrogen had been rising since the 1990s (LWIC, 2005). Algae thrive in phosphorus-rich and nitrogen-rich environments. Phosphorus and nitrogen occur naturally in soils, rocks and vegetation, and are required for plant growth, but accelerated levels of these nutrients can lead to nuisance algae blooms (LWIC, 2005). Scientific findings on Lake Winnipeg showed that phosphorus and nitrogen levels in the lake have been increasing since the second half of the twentieth century, and even more since the late 1990s, at a rate that could explain the increase in algae blooms during this period (EC, 2011: 6).

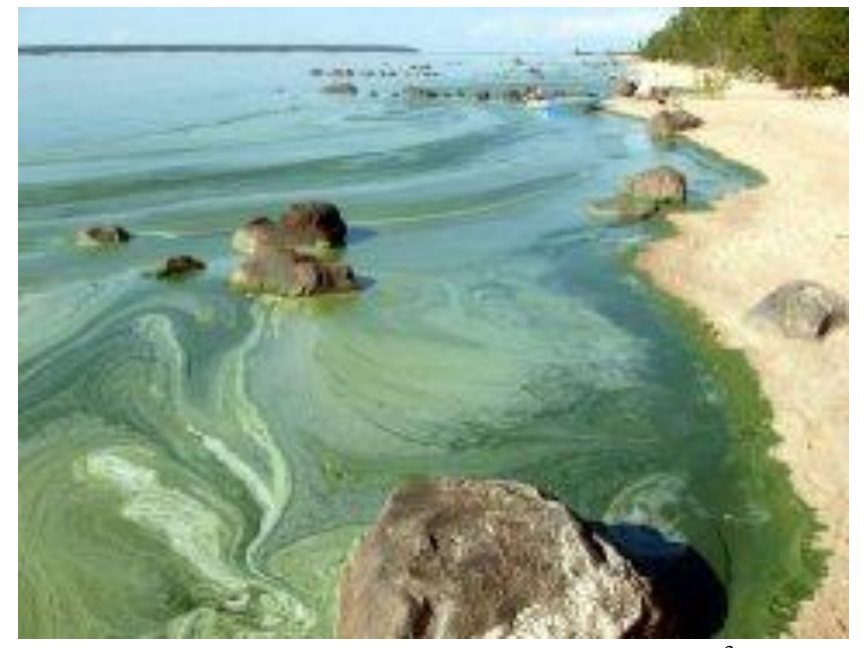

Blue-green algae on Lake Winnipeg, $2010^{3}$

Why was there more phosphorus and nitrogen in the lake now than there had been before the 1990s? Where were the excess nutrients coming from? Scientists produced findings showing that the increased phosphorus and nitrogen in Lake Winnipeg is caused by crop and livestock agriculture - the dominant economic activity within the Lake Winnipeg Watershed (Evans, 2000; LWIC, 2005; Lake Winnipeg Stewardship Board, 2006; EC, 2011; Leavitt et al., 2011). However, agriculture has been the dominant activity in this region of North America for over a hundred years, so why in the last 15 years were toxic algae blooming on the lake at such frequencies? In 2005, the Lake Winnipeg Implementation Committee (LWIC), a committee of scientists funded by the Canadian government, reported that the use of phosphorus-based fertilisers in the Lake Winnipeg Watershed has more

\footnotetext{
${ }^{3}$ http://canadawater.wordpress.com/2010/07/29/toxic-algae-warnings-not-just-lake-winnipeg-allover-north-america/
} 
than doubled from 1965 to 2000 (2005: 39). A Lake Winnipeg Stewardship Board (LWSB) (2006) report and a new report by Leavitt et al. (2011) both concluded that large-scale hog production is the largest contributor of phosphorus in the Lake Winnipeg Watershed. This is because phosphorus that gets consumed by livestock gets excreted in the manure. Manitoba had experienced an explosion of large-scale industrial hog production during the 1990s (Novek, 2003), which was around the time the toxic algae started increasing dramatically in Lake Winnipeg. City sewage also contributes to the increased levels of phosphorus in Lake Winnipeg - the LWSB (2006) report revealed that sewage from Winnipeg contributes seven per cent of the phosphorus that enters the lake (p. 40). The new Leavitt et al. (2011) report stated that the city's contribution of phosphorus to the watershed is more like 10 per cent.

Advances in lake science enabled the Manitoba Government to create new laws and regulations to help protect the lake. In June 2011 the Manitoba Government introduced the Save Lake Winnipeg Act, which tightens rules for expanding hog farms, protects wetlands from being drained for agricultural use, and forces the City of Winnipeg to build a treatment plant to filter phosphorus from its wastewater (Manitoba Bills, 2011).

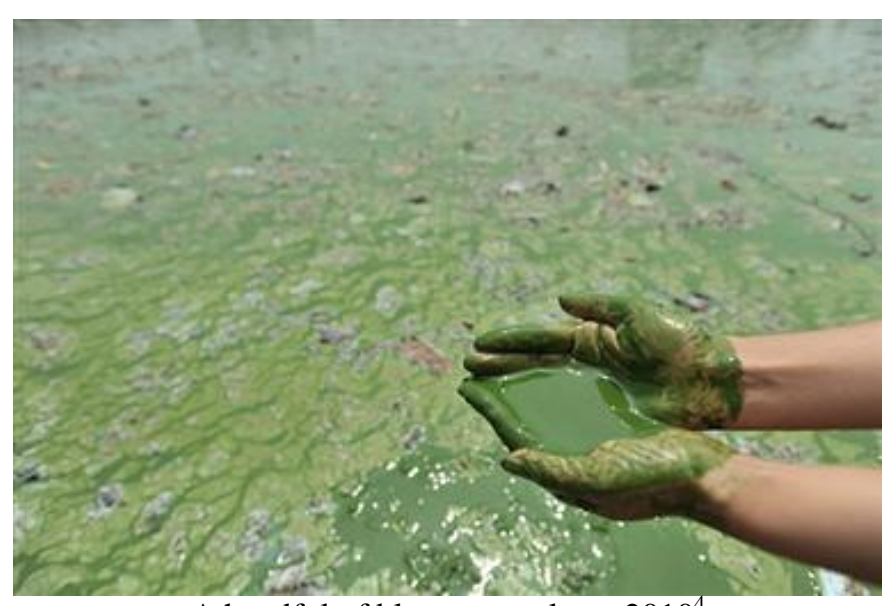

A handful of blue-green algae, $2010^{4}$

Introducing the Save Lake Winnipeg Act in 2011 would appear to be a positive step for a province concerned with protecting Lake Winnipeg. However, the news coverage throughout 2011 of the Act and the science behind it conveyed the message

\footnotetext{
${ }^{4}$ http://www.globalwinnipeg.com/feds+lack+knowhow+to+deal+with+dirty+rivers+and+lakes+ report/87950/story.html
} 
that these steps were far from positive for the province. News coverage of the regulations maintained a concern for saving Lake Winnipeg, while simultaneously doubting the science behind the Act, criticizing the government for "foolishly" listening to "bad" science, and relaying the message that the regulations would cost the economy. The coverage also conveyed the message that the hog industry was "hurt" by the regulations. How could the government have "singled them out" like this? Didn't the government "care" that these regulations were going to "cost jobs" and hurt "family businesses"? The message in the news coverage was that everyone agreed that Lake Winnipeg needed to be saved, but the government was going too far by introducing regulations to protect it.

The media coverage of the Save Lake Winnipeg Act left the public with unanswered questions. Was the science really "bad"? Was the government really "foolish"? Was the hog industry really being unfairly "singled out"? Were the regulations really going to cost jobs? Was the Save Lake Winnipeg Act really going to save Lake Winnipeg? Environmental discourse involves more than questioning the science behind governmental environment policies. There is a need to conduct discourse analysis on news discourse to understand the treatment of scientific claims by news media. Moreover, it is important to understand how, and why, media institutions frame environmental stories. In this thesis, I examine the environmental news coverage of the Save Lake Winnipeg Act. I ask, what is the impact of environmental news discourse on the public debate around environmental issues?

\subsection{Methodology}

This research looks at how the Winnipeg Free Press newspaper covered the Manitoba Government's Save Lake Winnipeg Act and the reaction to the Act by the City of Winnipeg, the hog industry and the public. The Winnipeg Free Press is a daily newspaper based in Winnipeg, Manitoba, Canada with the largest reader audience of newspapers in Manitoba (Winnipeg Free Press, 2012). For this research, I searched an online database for news articles about Lake Winnipeg that were published in 2011 in the Winnipeg Free Press. I initially found 365 articles that mentioned Lake Winnipeg. I then categorised the articles by lake-related topic 
and discarded the articles that did not directly relate to an environmental problem. This left me with 130 articles from which I distinguished four thematic narrative frames. I have chosen to talk about two of those narrative frames to provide a manageable scope for the research - the nitrogen debate and the blaming hog farmers narrative frame. Appendix I shows a list of the 130 articles analysed. I narrowed my scope again to focus only on articles that related to the Save Lake Winnipeg Act, although I include some quotes from articles outside of this scope, such as examples of people talking about their cultural connections to the lake in Chapter Three.

I believe the study of environmental problems and politics is necessarily interdisciplinary, so I employ sources and theoretical perspectives from a range of academic disciplines including sociology, media studies, history, anthropology and linguistics. I use a three-lens theoretical approach in my analysis. The following three lenses represent three theoretical assumptions about the political-economic environment the Lake Winnipeg problem exists within:

1. Political economic lens: The environmental crisis is systematically perpetuated as part of a larger crisis of industrial society. There is a tension between environmental and economic paradigms.

2. News media lens: The public sphere is a discursive arena where environmental politics are negotiated. News media are central to shaping environmental discourse and politics.

3. Treatment of science lens: Uncertainty in environmental science is socially constructed and maintained in news media discourse.

I use critical discourse analysis (CDA) to analyse the news articles. Discourse is defined by Cox (2006) as a pattern of meaning communicated through language and other symbols (p. 58). CDA is based on the social constructionist perspective that "discourse is shaped by the world and discourse shapes the world" (Bax, 2011: 96). CDA provides greater understanding for the power relationships that are gained or maintained through text - that is, the sociological implications of what is said or written (Bax, 2011: 33). CDA is also a framework for understanding how words, language and discourse construct individual viewpoints and perceptions. My 
approach incorporates the assumptions that discourse reflects the way reality is constructed by society, and also that discourse has an effect on further constructing that reality.

My approach considers an analysis of media story-telling, narratives and framing. In Environmental Sociology (2006), John Hannigan describes discourse analysis as the analysis of "an interrelated set of 'story-lines' which interprets the world around us and which becomes deeply embedded in societal institutions, agendas and knowledge claims" (p. 37). I consider sets of story-lines in my analysis and their meanings within their socio-political context.

I ask the general questions that Bax (2011) recommends for conducting critical discourse analysis on news media texts. The table below lists Bax's questions for analysis including questions specifically for news media texts (2011: 143-5). I consider these questions in my analysis.

\section{Questions for analysis of news media discourse (Bax, 2011)}

\section{GENERAL CDA QUESTIONS}

- What is the text doing?

- What effect does the text have on the reader?

- How does the text do what it does?

- What patterns are apparent in the text?

- How is meaning created in the text?

- How is the text serving to reflect on or construct a social problem?

- What ideologies and viewpoints are reflected in the language used in the text?

- How are these ideologies and viewpoints further reinforced by the text itself?

- How is the language serving or demonstrating social relations of power?

\section{NEWS MEDIA CDA QUESTIONS}

- Why are some words chosen over others in the telling of the story?

- What effect do these words have on the reader?

- Where is the writer's choice of focus?

- How does the writer control the topic by emphasizing certain parts of the story and brushing over others?

- What alternatives were there to presenting the material?

- What does the order in which information is given in the article say about where the author's focus is?

- Why has this order of presenting the information been chosen? 
I developed an additional set of questions to ask of the material, based on my three thematic lenses. These questions are listed in the table below. After asking these questions of the news coverage separately, I then looked at how the themes interact with each other in the news coverage of the Save Lake Winnipeg Act.

Questions for analysis based on three theoretical lenses

QUESTIONS RELATING TO THE POLITICAL ECONOMY

- Whose values are presented on the environment?

- Who does the claim come from?

- What resources do they have to make the claims?

- Are environmental and economic goals presented as conflicting? Which comes out 'on top'?

\section{QUESTIONS RELATED TO MEDIA DISCOURSE}

- What story-lines and narratives are used to communicate the issues?

- Are the stories decontextualised from their socio-political origins? Are they then re-contextualised into a particular media frame?

- Is there evidence of an attempt to achieve 'balanced' reporting by the journalists? What is the effect of this?

- Do environmental issues get dramatised as stories with a protagonist and antagonist? What is the effect of this?

- Does the issue follow a life-cycle? What causes the rise or fall of the issue as a top news story?

- What aspects of the issue are not discussed in the news articles?

\section{QUESTIONS RELATED TO SCIENCE}

- How do the news articles use science to support their information?

- Is the news coverage skeptical of environmental science?

A note on the use of science in the thesis: I use scientific research throughout the thesis to explain the ecological state of Lake Winnipeg. I rely on the science while applying the precautionary principle recommended by the majority of theorists (Hannigan, 2006; Cox, 2006; Wynne, 1996). The precautionary principle is based on the idea that scientific inquiry is, by definition, always incomplete, with an inherent degree of uncertainty. However, if the majority of current evidence available reveals situations where humans have caused harm or could cause harm if action is not taken, then that action should be taken to try to eliminate or reduce the 
harm done. Action should be taken even in the absence of scientific consensus because by the time consensus is reached, if it is ever reached, it may be too late (Hannigan, 2006: 97). I, therefore, acknowledge that the current pool of scientific knowledge on Lake Winnipeg is imperfect and may contain uncertainties. I proceed anyway to engage with the science because of what I perceive to be an urgent need to address the environmental problem politically. It is beyond my intention (and expertise) to doubt or confirm existing science, but it is my intention to describe how the science is used in the narratives, and to compare patterns of doubting science in the coverage with similar patterns found in news discourse historically.

I argue that the environmental rhetoric in the news coverage of the Save Lake Winnipeg Act is voiced by all participants in the discourse, and yet the coverage excludes any real discussion of the issue. In Chapter Two, I provide a literature review and theoretical framework of the central themes of my argument - mainly, the environmental/economic tension, the influence of a media political economy on news discourse, and the representation of environmental science in the news. I draw on Klaus Eder's (1996) theory of post-environmentalism to define the current phase of environmental discourse on Lake Winnipeg in post-environmentalism. In Chapter Three, I describe my findings and analysis, and present the two narrative frames found in the coverage. I show that the Save Lake Winnipeg rhetorical motif is a symbolic package 'on offer' in a public-sphere-turned-marketplace. The motif is repeated by all participants in the discourse including governments and industries. Rather than serving to enhance the awareness of the pollution in the Lake Winnipeg Watershed in the public sphere, the shared voicing of concern for the cause is used to legitimise various positions including that of the environmental opposition. In Chapter Four, I discuss my findings in relation to the three theoretical lenses and literature, and conclude my argument. I explain that in its treatment as a mainstream topic, the Save Lake Winnipeg rhetorical motif becomes part of what Eder describes as an environmental masterframe, and thus enters a postenvironmentalist phase of the discourse. 


\section{Environmental News Discourse in a Public-Sphere-Turned-Marketplace}

\subsection{The environmental/economic paradigmatic tension}

When the environmental movement began in the mid-twentieth century, the discourse was dominated by environmentalists leading a movement. Environmentalists communicated messages to the public that challenged existing ways of life. Environmentalism initially emerged as a counter-discourse because it came into conflict with mainstream understandings and assumptions about human progress and development (Eder, 1996: 203). In 1974 Dunlap and Ehrlich came up with the term Dominant Social Paradigm to identify commonly held assumptions about how the world is and how it should be organised (in Dunlap and Ehrlich, 2008). The Dominant Social Paradigm contains assumptions that a) economic growth is generally desirable for human progress, and b) science and technology provide society with solutions to social and environmental problems (Hannigan, 2006: 88).

Although Dunlap and Ehrlich used the term 'paradigm', Cox (2006) suggests that it is perhaps better understood as a discourse (p. 58). Dominant discourses are the taken-for-granted patterns of meaning found in how individuals talk about the world and, as such, are often invisible (ibid.: 58). In policy-making, taken-for-granted assumptions such as the Dominant Social Paradigm are used to justify the creation or maintenance of policies (ibid.: 59). For example, economists may reference 'growth' and 'progress' in policy-making, referring to assumptions that 'we all know' about the best means of human progress via economic growth.

The Dominant Social Paradigm has been challenged and continues to be challenged by environmentalism. Environmentalists reject the idea that the earth's resources are abundant, and that nature exists purely for human use and consumption (Dunlap 
and Ehrlich, 2008; also see Cox, 2006: 59). Dunlap and Ehrlich refer to the views of environmentalists as the New Environmental Paradigm. The New Environmental Paradigm contains assumptions expressed by environmentalists, that a) there are limits to economic growth; b) the earth's resources are limited; and c) human progress should be obtained through restoring ecological balance (Cox, 2006: 59). The emergence of the New Environmental Paradigm has created a tension with the Dominant Social Paradigm (Alan Schnaiberg, 1980; in Hannigan, 2006: 20).

The environmental crisis is part of a larger crisis of industrial society; it is increasingly being realised that environmental destruction will continue so long as global industrial processes continue and expand. Ulrich Beck's (1996) risk society theory describes the environmental crisis as an institutional crisis that is bound within a dysfunctional global economic system of industrial production and consumption (p. 32). Industrial production requires a "legalisation of hazards" because it relies on continually extracting resources from the environment, as well as disposing of industrial waste by dumping it back into the environment (Beck, 1996: 23). Finger-pointing and responsibility-assigning occurs within a public conflict of accountability discourse (Hannigan, 2006: 28). However, the environmental problems of technologically advanced industrial societies can span large geographical locations and occur over long periods of time, so causation and blame can be difficult to prove (Hannigan, 2006: 23).

The government has a dual and conflicting role to support economic growth and provide environmental protection (Hannigan, 2006: 20). This often results in governments engaging in 'environmental managerialism' - a process where governments issue a degree of legal protection and regulations for the environment but not enough so that they impede on economic growth (Redclift, 1986; in Hannigan, 2006: 21). Similarly, Hays (2000) describes the emergence of an 'environmental economy' in public policy, whereby the impacts of environmental policies are evaluated in economic terms. As a result, almost every environmental political discussion includes a discussion around whether efforts to protect the environment are worth the cost (Hays, 2000: 155). In the United States, this has 
historically been followed by an economist providing an expert cost-benefit analysis of the initiative in the discourse, under the guidance of "good science" (Hays, 2000: 162).

Within environmental economic discourse, governments and industries attempt to jointly meet economic and environmental needs through 'win-win' situations usually through scientific and technological advances that streamline industrial production (Hannigan, 2006: 22). The 'win-win' approach to environmental problems and policies is also described as the ecological modernisation approach (Mol and Spaargaren; in Hannigan, 2006). However, there is no discussion, within the ecological modernisation approach, around exactly how ecological needs will be made a priority for business and industrial leaders, whose primary aims are to produce revenue and grow industries (Hannigan, 2006: 26). For example, Emily Yeh (2009) looked at a series of construction projects in China that claimed to improve the environment while growing the economy at the same time - a 'winwin'. Yeh's study showed how, through ecological modernisation policy models, the Chinese government assigned the task of protecting the environment to those whose primary goals are to further industrialise China. Yeh argues that ecological modernisation washes over the enormity of the ecological crisis by assuming that 'green' values will be primarily considered over already established economic values (p. 844). Ecological modernisation approaches to environmental policy attempt to bridge the gap between conflicting environmental and economic needs. However, by assigning the role of solution-finding to industries, these approaches further legitimizes these industries to act in the environment.

Governments re-affirm the control the industries have over the environment by referring to the environment discursively as a 'resource'. Environmental policies are discussed in relation to the Dominant Social Paradigm. Timothy W. Luke (1995) explains that environmental discourse, found particularly in scientific and technological texts, is predicated on the idea that nature is a resource that serves human economic processes, and must be managed to secure its future use (p. 70). Governments often mobilise dominant understandings of society and the environment in their discourse, and in doing so further rationalise these frames as 
truth (Luke, 1995: 69). Yeh (2009) argues that there is a need for discourse analysis to reveal political motivations behind government projects that are hidden when we do not consider these projects as "discursive projects" (p. 884). Similarly, Hannigan (2006) states that "the central task ahead for environmental sociologists is...to demonstrate that they are the products of a dynamic social process of definition, negotiation and legitimation" (p. 31).

The environmental movement started out as a counter-discourse that challenged the Dominant Social Paradigm. It has since become redefined by powerful actors. The fate of global ecological systems, on which the survival of all life on Earth depends, has been placed in the hands of the very actors and systems responsible for perpetually causing damage to the environment. In Klaus Eder's (1996) theory on post-environmentalism, described in "The institutionalization of environmentalism: ecological discourse and the second transformation of the public sphere", Eder argues that the increasing presence of different voices speaking about environmentalism shows that environmentalism has gained public consensus - that is, it has become a masterframe that is not just discussed by environmentalists anymore (1996: 204). Eder argues that once environmentalism has become accepted as a masterframe in public discourse, this marks the transition into postenvironmentalism - a phase of the discourse where environmentalism is mainstream, and not seen as a counter-discourse (1996: 207). He states, "The age of environmentalism, the collective mobilization for a cause, is over. The age of postenvironmentalism begins when ecology is established as a masterframe that can be referred to by all actors" (1996: 206). The discussion around symbolic legitimacy claims-making in this chapter considers Eder's position in more detail.

\subsection{News media in the public sphere}

To address the environmental/economic paradigmatic tension in the public sphere, transparent communication about environmental problems is required. In 1999, transparency of information about the environment was declared by the United Nations as a human right that is essential for any democratic society, when it stated, "everyone has the right to access to information on the environment with no obligation to prove a particular interest" (in Cox, 2006: 86). 
News media are the primary source of environmental discourse in the public sphere. Jürgen Habermas' public sphere model, first described in 1962, is a discursive arena where public policy is debated and public opinion is communicated and formed (Habermas, 1989; also see Fraser, 1992: 110). The public sphere fulfills the rights of citizens in a democracy by allowing the public to comment on proposed policies and government actions (Cox, 2006: 85). News media have a significant role in maintaining transparency in public sphere discourse, because they communicate information about social and environmental problems so that citizens are informed enough to engage in public debate. News media also supply the public with the majority of information about the activities of corporations (Sachsman et al., 2005: $365)$.

There is general agreement in the literature that news media messages influence public opinion, even though there is some debate around exactly how and to what extent. Individuals do not passively accept information, but are continually engaging in its critique, interacting with it, discussing it, and applying it to their dayto-day lives (Roberts and Crossley, 2004: 11-12). Couldry and Markham (2006) suggest that media researchers should not assume a one-way direction of influence of the media over a unified audience (p. 252). Boykoff emphasises that the public are a heterogeneous group, and different members of the public are differently influenced by the ideological forces of mass media (2009: 448). For Boykoff, "coverage does not determine engagement but perhaps shapes their possibilities" (2009: 448). Similarly, Cox suggests that the media does not determine what people think, but perhaps what they think about - in other words, it does not influence opinion but influences priorities, or sets the agenda (2006: 184). Although individuals receive these messages in different ways, what they see, what they do not see and how they see these messages is nevertheless influenced by how news media present information.

News media not only determine how messages about environmental issues are understood, but they also determine who has a say in public debate (Boykoff, 2009: 435-40). News media discourse is politically influenced both through micro- 
processes of professional journalism and through macro-power relationships of the wider political economy (Boykoff, 2009: 435-40) - both of which are discussed in the next two sections.

\subsection{News media micro-processes and environmental reporting}

Driven by increased economic pressures as well as advances in communications technology, the capacity of news media is shrinking. In the United States, since the global economic crisis began in late 2007, newspapers diminished in circulation and advertising revenue by 23 per cent, and one in five newspaper journalists have been laid off since 2001 (Boykoff, 2009: 445). The global economic crisis has impacted environmental communication directly - newspaper science sections shrunk by two thirds from 1989 to 2006, and in December 2008, CNN cut its entire science, technology and environment news staff (Boykoff, 2009: 445). Newspapers have become more limited in their capacity for investigative journalism, which is where the complexities of environmental issues are best represented. The shrinking capacity of news media has resulted in changed roles for journalists, as well as changed operations and practices of journalism in the last few decades (Hansen, 2010: 10-11). Increased time and financial pressures have caused journalists to become more desk-bound (Hansen, 2010: 11-12), which limits their ability to cover in-depth environmental problems. Sachsman et al. (2005)'s survey of 364 American journalists found that journalists reported time pressures, financial constraints and the size of the "news hole" as their biggest challenges to reporting on the environment (p. 370).

Increasing financial and time pressures influence how journalists frame issues. More and more news reporting companies are owned by consolidated business owners, who place pressure on journalists to report stories in a way that is favourable to the business climate in which they operate (Cox, 2006: 172). Similar financial pressures have been placed on Canadian newspapers but to a lesser degree than in the United States. Joining the trend of consolidation into bigger media companies, the Winnipeg Free Press was purchased by FP Canadian Newspapers Limited Partnership in 2001 - a company that owns one other newspaper in Canada (Winnipeg Free Press, 2012). News editors decide the size of the "news hole" an 
issue is covered in, and the size of news holes is shrinking with increased time and financial pressures (Cox, 2006: 173). News media companies are gatekeepers for the environmental stories that get reported and the ones that do not (Cox, 2006: 174). These decisions are based on what is beneficial to the journalist, news room and editor at the time of reporting, and do not necessarily reflect the needs of democratic debate in the public sphere. Newspapers have come to cater to an audience of consumers rather than an audience of citizens (Garnham, 1986: 8 and p. 37).

As a result of pressurised newsroom production, environmental news stories tend to be covered as one-off bits of information. This can mean only reporting environmental problems that are "breaking stories", and neglecting more long-term, slow-burning problems (Hannigan, 2006: 92). The effect is that the stories become decontextualised from their causes because journalists do not ask why a problem or event has occurred (Hannigan, 2006: 80; Hansen, 2010: 14). Context is important for helping to understand the credibility of claims and counter-claims, and to help the public understand how issues affect them directly (Boykoff, 2009: 441). Decontextualising environmental problems can also make it seem as though the problems have a singular cause. That is, events are not placed in context with larger political and economic systems (Hannigan, 2006: 85). Giannoulis et al. (2010) document a list of studies concluding that as a result of news media covering environmental problems as one-off, local stories, readers fail to understand the complexity and interrelatedness of environmental issues (p. 431). The media, in an attempt to accurately communicate environmental problems, can end up bewildering the public (Boykoff, 2009: 440).

Environmental news stories can also become re-contextualised into constructed narrative frames. An example is shown in Maier's (2011) analysis of a television episode on "greenwashing" (referring to companies falsely advertising their products as 'green') on a CNN program called Eco Solutions. Maier observed that the episode framed the issue by including certain information, excluding other information, and selecting the order in which the information was presented (2011: 168). The episode did not show the faces of the company representatives accused of "greenwashing", nor did the episode name the companies - it only showed close- 
ups of their logos. These processes of selection had the effect of de-personalising the individual companies, thereby reinforcing their position of blame. Maier concluded that media discourse can re-contextualise issues into constructed media frames.

Journalists aim to provide balanced and objective reporting. Because of a balanced reporting principle held among the field of journalism, journalists try to present two sides of any debate (Boykoff, 2008). However, sometimes a balanced view is given even when one view is expressed by a majority of people, and the other only represents the opinion of a small few. Research on news coverage of climate change has shown the downside of the journalistic principle of balance. Boykoff (2008) looked at television news media reports on climate change from 1994 to 2004 in the United States, and found that 70 per cent of reports 'balanced' the view of anthropomorphic climate change with the view that current climate change trends are caused by natural forces, giving each point of view equal perspective. This was done despite almost complete consensus within the scientific community that human activities have caused global climate change (Boykoff, 2008: 1). Boykoff argues that,

\footnotetext{
"All aspects of environmental issues should not be treated equally. There are faces of environmental change where consensus is strong and convergent agreement dominates, and in others, disagreement garners worthwhile debate and discussion" (2009: 441).
}

Drawing on LaMay (1991), Cox suggests that journalists could do better at providing more explicit advocacy for the "better argument" in environmental news stories, to help provide guidance for readers (2006: 182).

To capture wide audiences and increase revenue, media companies try to entertain readers by dramatising news stories. Environmental news stories can be particularly prone to bring framed in sensationalist ways because of their otherwise unobtrusive nature (Cox, 2006: 170). Environmental news stories tend to draw on the personalities of those involved in the story, which can trivialise the issues (Giannoulis et al., 2010: 428). American news media in particular have a pattern of reporting environmental science findings as contentious and conflicted, as opposed to convergent or having consensus within the science community (Boykoff, 2008: 6). 
The need to appeal to wide audiences can result in news stories being presented as dramatised binary conflicts (Lockie, 2006).

Robert Babe (2005) analysed news coverage in one Canadian national newspaper, The Globe and Mail, of Canada's participation in the Kyoto protocol. Babe's analysis provides an example of an environmental story framed as a political drama. The Kyoto protocol is a global agreement committing 160 countries to targets to reduce greenhouse gas emissions, the major contributors to global climate change (Babe, 2005: 196). When, in 2002, United States President George W. Bush announced that the United States would not sign the protocol, the Canadian government nearly gave in to pressure to not sign the protocol as well (Canada did eventually sign the protocol in December 2002). Babe found that rather than focusing on the protocol's environmental implications, the story was framed by The Globe and Mail as a political conflict between provincial and federal governments, as well as a duel of personality between two politicians (p. 199). The majority of articles presented the view that signing the protocol was not a good option for Canada, mainly for economic reasons (Babe, 2005: 217). The Globe and Mail's main environment reporter at the time did not cover the story at all - much of the coverage was written by leading business, financial and political reporters. The major voices in environmental reporting were ignored, as were the opinions of NGOs and environmental groups around the issue (p. 216-9). Babe's analysis is useful because it highlights what was not covered in the news stories. Omissions can be a significant source of political influence in news media discourse.

Because of increasing pressures to produce news in a fast-paced environment, journalists often rely on a shortlist of professional sources to provide a story. Hannigan (2006) describes the news making process as "a collaborative process in which journalists and their sources negotiate stories" (p. 80). Sources are usually people in the professional world, such as public relations representatives of companies, politicians, government agencies, scientists or other experts (Hannigan, 2006: 81). Journalists have become increasingly reliant on professional sources not only to supply the news, but also to supply the "spin" or angle in which to frame the issue (Hansen, 2010: 11). Because many journalists lack the scientific expertise to 
assess the validity of environmental science, they rely even more on sources to tell them whether the science is sound (Hays, 2000: 219). The process of journalists relying increasingly on professional sources is described as the authority-order bias (Giannoulis et al., 2010: 428). The result of the authority-order bias is that the sources exercise an imbalance of power over the ability to influence how issues are communicated to the public (Hannigan, 2006: 81). The sources often exercise more power over the story than journalists and media professionals themselves (Hansen, 2010: 11).

\subsection{The media political economy and legitimacy claims-making}

In addition to the journalistic practices that influence environmental news, the media political economy also influences environmental discourse. One of the challenges to the media providing democratic transparency is that media companies are not impartial observers of politics. Their chance of survival as corporate entities improves in political environments that favour their ability to generate profit. Yet, as a major source of political information for the public, media companies have a hugely influential capacity to affect public opinion (Boykoff, 2008: 44). As a result, news tends to be framed in way that supports the views of corporate shareholders. Environmental news stories are more likely to be successful when they align with the assumptions contained within the Dominant Social Paradigm (Hannigan, 2006: 88). Cox (2006) calls this the media political economy (p. 172).

The media political economy does not make it so that news always aligns with powerful corporate leaders. Although the journalistic principle of balanced reporting can have its downsides, it can also give a voice to the concerns of communities (Cox, 2006: 173). The balanced reporting journalistic principle is upheld for many environmental news stories. Sachsman et al. (2005) surveyed 364 American journalists and found that 98 per cent agreed or strongly agreed that "environmental journalists need to be fair to sources such as corporations"; a slightly smaller percentage but still an overwhelming majority of journalists agreed that environmental journalists should also be fair to environmental groups (p. 370). However, news editors are "more likely to be sensitive to external pressures from corporate advertisers and other powerful supporters of the status quo" (Hannigan, 
2006: 86). Howard-Williams' (2011) study on representations of the environment on New Zealand television indicated that it is difficult to make social progress on environmental issues in a media environment that is so closely connected to commercialism and business (p. 41).

News media serves the political economic domain by acting as a vehicle for the legitimacy claims-making of powerful corporate actors. There is a conflict of accountability discourse that accompanies the discussion of environmental problems, consisting of a pattern of assigning blame. The conflict of accountability discourse calls for accused parties to defend themselves with claims that they are not responsible for causing environmental harm. Eder describes the environmental crisis as a "legitimation crisis" (pp. 209-10) and argues that various governments and institutions try to convince the public of their legitimacy so that they will not be seen as responsible for environmental problems. Robert Cox's (2006) book Environmental Communication in the Public Sphere outlines the process of legitimacy claims-making in environmental discourse. Cox defines legitimacy as the right to act. According to communications scholar Robert Francesconi (1982; in Cox, 2006: 60), legitimacy is claimed by actors, but must be given by others. This is why legitimacy claims-makers go to great lengths to convince the public of their claims.

News media organise who is speaking - that is, whose positions are being represented in environmental discourse. Cox (2006) identifies the main voices participating in environmental claims-making as citizens, community groups, environmental groups, anti-environmental groups, scientists, corporations and business lobbyists, and journalists (p. 20). Similarly, Hannigan (2006) maintains that the typical claims-makers in the discourse include scientists, politicians, journalists, and environmental activists (p. 63). However, these voices are not treated equally in the news. The success of a claim in environmental news media is largely determined by the amount of economic and organisational resources actors possess, as well as their level of political power (Hansen, 2010: 20). Hannigan explains that most of the discourse takes place between powerful institutions with the means to make decisions about environmental policy (2006: 37). Babe's (2005) 
study of environmental news coverage in Canada found that business leaders were given higher credibility in environmental news stories than were "concerned citizens", who were often denigrated for not having enough knowledge on the topic (p. 218). The claims-maker's level of political power, thus, determines their ability to participate in the environmental news discourse, as well as the amount of credibility their claims will be given (Hanson, 2010: 21).

Until the 1980s, environmental discourse was communicated primarily by environmentalists and environmental organisations. Since then, the discourse has become increasingly dominated by opponents of the movement (Eder, 1996: 203). Many different voices in the public sphere now compete to gain public acceptance of their position on the environment. In his theory on post-environmentalism, Eder (1996) explains that the public sphere has been transformed, by media politics and various other political economic forces, into a marketplace. I refer to this transformed public sphere as a public-sphere-turned-marketplace. In the publicsphere-turned-marketplace, actors in the public sphere must compete to influence media discourse. Media frames are used to organise news stories so that they align with political ideas and, as a product of this, different social and political actors (such as governments, industries, citizens, or scientists) compete to influence the framing of news stories (Cox, 2006: 178). In a case study on Chile's La Ligua river basin, Jessica Budds (2008) looked at how different socio-political powers exercise different agency in shaping media discourse. Budds found that the Chilean news media framed solutions to environmental problems as administrative or technical, which gave the impression that the problems were both manageable and being managed effectively by the industries that were causing the damage.

Institutions and organisations generally have more legitimacy claims-making power and resources than individuals, which has further segregated individuals and environmental groups from participating in the discourse. Mühlhäusler and Peace (2006) conducted an ethnolinguistic analysis of environmental discourse in the media. They identified the participants in environmental discourse, which included the category of "the addresser" as "the source of the message" (Mühlhäusler and Peace, 2006: 459). Mühlhäusler and Peace found that the addresser has evolved 
throughout the environmental movement from concerned individuals to national and international organisations (2006: 460). Governments too have increasingly taken on the role of the addresser, who is "speaking on behalf of the Earth", according to Mühlhäusler and Peace (2006: 460). This move away from environmentalists as individuals or grassroots groups, and toward the environment being represented by corporate organisations and governments, relates to Eder's description of the transformation of the public sphere. The news media that operates within the public-sphere-turned-marketplace are now dominated by the legitimacy claimsmaking process, and environmentalists have had to adapt to this through increased organisation. Environmental groups now have to carefully consider and organise their media campaigns and messages (Craig, 2010: 7).

Interestingly, while environmentalists need to become more organised to compete for 'ownership' of the media's message on the environment, the environmental opposition are able to remain deliberately invisible. The invisibility of the environmental opposition is the very reason why it seems unusual to refer to an environmental opposition at all, since no one in public discourse is openly identifying with this label. The transformation of environmentalism into a masterframe, according to Eder (1996), means that claiming to support the environmental cause is now a powerful legitimacy tool. It is, thus, beneficial for actors who are opposing environmental policies to do so through means that avoid any public announcement that they are 'anti-environmental'. Rather, the environmental opposition gain legitimacy by aligning anti-environmental agendas with agreed-upon dominant assumptions, such as those of the Dominant Social Paradigm. Anti-environmental messages in the news typically sound like this: "we do care about the environment, but we just cannot afford the cost" or "we do care about the environment, but we do not know enough about the problem - we need more science before we can act" (I discuss this second message in more detail later in the chapter).

Not much is known publicly about the groups and individuals who make up the environmental opposition. However, in A History of Environmental Politics Since 1945, Samuel Hays (2000) acknowledges their existence by giving them a name, and 
attempts to understand how they have influenced the environmental movement in the United States throughout its history. For Hays, environmental politics throughout the second half of the twentieth century has involved three sets of actors - protestors and environmentalists (groups and individuals), government institutions responsible for policy development and implementation, and the environmental opposition (2000: 2). The environmental opposition has been the most under-studied of these groups, and Hays suggests that this is because they purposefully remain under the radar of public identification and prefer subtle, secretive methods of influencing environmental policy (2000: 109). Hays proposes that the two main groups who oppose environmental objectives are either deeply rooted in older, traditional values of the American past and view environmental reform as a threat to these values, or else they are rooted to contemporary economic interests and view environmental action as a threat to these activities (2000: 109).

News media rarely identify the environmental opposition or what exactly they are opposing. Their views are best understood to be reflected in the realm of policy activity where corporations and industries have had substantial influence, via financial contributions to legislators as well as media campaigns aimed at shaping public perception (Hays, 2000: 112). Often policies are shaped by the interests of the opposition in the minute details of regulation that get overlooked by media attention, in part, because they lack the drama required to make a newsworthy story (Hays, 2000: 113). Processes for implementing regulations are even less documented than the regulations themselves, and this is another area where the environmental opposition's interests dominate (Hays, 2000: 114).

The area of influence where the environmental opposition is least documented, according to Hays (2000), is their use of public relations campaigns to brand themselves as 'green' (p. 115). This is otherwise known as greenwashing (Hays, 2000: 229; Hansen, 2010: 12; Mühlhäusler and Peace, 2006: 461; Simon, 2009: 89). Since the 1990s, the environmental opposition has taken a strategic public stance that they now support the environmental movement, and have been reformed to become 'green' (Hays, 2000: 119). Corporations participate in environmental discourse both through "brown-lash" - that is, minimising the perceived severity of 
environmental problems, as well as through promoting the story that they have been through a 'green' reform (Mühlhäusler and Peace, 2006: 461). Companies often spend millions on rebranding themselves as 'green' during greenwashing campaigns (Simon, 2009: 89).

Greenwashing is post-environmentalism in action. Recall that Eder describes postenvironmentalism as the phase of the discourse when environmentalism has become a powerful symbolic package 'on offer' to be used by anyone claiming to be 'green'. Greenwashing is the process whereby actors of the environmental opposition use the environmental masterframe to aid their legitimacy claims. Hays (2000) states,

"One has to be ... skeptical of the continual affirmation from the business community that though it once opposed environmental objectives, it has now 'seen the light'. Often it is argued that 'we are all environmentalists'. That phrase usually means that one is willing, even anxious, publicly to affirm the importance of environmental affairs but, at the same time, equally anxious to make clear just what environmental objectives one is willing to support and which ones not" (p. 229).

In post-environmentalism, claiming to be 'green' is now used, not just to support environmentalist causes, but to support any position at all on the environment, including that of the environmental opposition.

In sum, the macro-power relations of the media political economy influence how environmental stories are told in the news. As a result, more stories are told that align with the dominant discourses maintained as part of the Dominant Social Paradigm about the pursuit of economic growth and development. Within the public-sphere-turned-marketplace, news media allow for powerful actors to dominate news media messages to aid their legitimacy claims-making. In their coverage of environmental issues, news media support greenwashing campaigns of corporations and industries by framing stories so that they align with the messages contained in corporate greenwashing campaigns. Restoring democratic transparency of environmental issues and politics should include unveiling the carefully maintained invisibility of the environmental opposition. Doing so would shed light on their means of obtaining substantial influence on environmental policies, as well as their influence on shaping environmental discourse in news media. Because the issues are decontextualised in the discourse, it is not apparent 
to the public whose voice is being represented by the coverage. The result is that the stories do not appear to the public as public relations campaigns for powerful actors to claim legitimacy in opposing environmentalism. Instead, the stories appear simply as news.

\subsection{Rhetoric and framing to aid legitimacy claims-making}

In environmental news discourse, rhetoric, symbolism, narrative framing, and the construction of issue life-cycles are all powerful techniques used in legitimacy claims-making processes. The public sphere is a discursive arena, so media communication - its use of language and nonverbal symbols, what it chooses to focus attention on, what it chooses not to focus attention on, and how it frames issues - impacts how issues are understood by the public. News media shape public discourse on the environment through the use of verbal and nonverbal symbols (Cox, 2006: 13; Hannigan, 2006: 81; Eder, 1996: 206; Hays, 2000: 3). Symbolic and stylistic devices such as metaphors and catchphrases are used as "interpretive packages" in the media to help the reader relate new or problematic stories to what they already know about the world (Gamson and Modigliani, 1989; in Cox, 2006: 178). Rhetorical motifs are recurrent metaphors or figures of speech used in media discourse to inject an issue with moral significance (Ibarra and Kitsuse, 1993; in Hannigan, 2006: 65). Policy is only partly informed by facts about social and ecological needs; it is also influenced by symbolic associations in the rhetorical discourse of politicians, business leaders, journalists and the public (Cox, 2006: $338)$.

Symbolic packages are the assets on offer in a discursive public-sphere-turnedmarketplace. Actors compete over how these symbolic packages are framed and communicated in the media according to their desired messages. Eder (1996) explains that as soon as a message enters public discourse, the protest actor who originally communicated the message must compete for its control because it has now become a symbolic package 'on offer' for anyone's use (p. 206). Eder suggests that the public-sphere-turned-marketplace serves to "reorganise the discursive field of politics" by reorganising who is speaking on behalf of the environment (1996: 205). Eder describes environmentalism as a "central symbolic 
asset" used in public discourse (1996: 209). In other words, it has become a powerful form of legitimacy to be seen as 'green'. According to Eder's postenvironmentalism theory, environmental messages are assimilated into regular public discourse so that they are no longer 'owned' by subversive protest actors, but by everyone claiming to be a legitimate speaker or actor for the environmentalist cause (1996: 204). The environmental masterframe is transformed into a symbolic package used to mobilise legitimacy (Eder, 1996: 207). Eder states that "the more that environmentalism serves for generating legitimacy, the more it becomes an ideological weapon in political discourse" (1996: 204). In post-environmental discourse, environmentalism has, thus, become an ideological weapon used against itself.

News media coverage organises and constructs issues into media frames. The concept of frames was first popularised by Erving Goffman (1974) and was subsequently used by media theorists such as Pan and Kosicki (1993; in Cox, 2006) and Rodriguez (2003). Frames are "central organizing themes" (Rodriguez, 2003: 80; in Cox, 2006: 178) or "organizational devices" (Hannigan, 2006: 81) that suggest what is at issue. News media frame issues by drawing attention to them and talking about them as important problems (Cox, 2006: 167; Hannigan, 2006: 81). Narrative framing is the organisation of information into a story to give it meaning (Cox, 2006: 188). Narrative framing is influential over the material because it constructs actors into protagonists or antagonists by assigning moral characteristics to the actors (Cox, 2006: 188).

Issues in the news follow an issue life-cycle; news coverage on an issue typically has a rise, fall and end. I describe issue life-cycles as meta-frames constructed by news media discourse. Looking at coverage of climate change in The New York Times and The Washington Post between 1980 and 1995, McComas and Shanahan (1999) found that environmental issues go through life-cycle phases, and different ideological symbols and rhetoric are used in each phase. In the first 'waxing' phase, the cause for concern is constructed, often with the use of apocalyptic rhetoric. Laura Johnson's (2009) analysis of Al Gore's 2007 documentary on climate change, An Inconvenient Truth, demonstrates how apocalyptic rhetoric is 
used to emphasise the seriousness and urgency of the environmental issue during its waxing phase. During the second 'maintenance' phase, the issue is shown by the news media to be managed through administrative or technical solutions, government policies and regulation. Lastly, the issue goes through a 'waning' phase. Economic consequences tend to be a topic of concern during both the maintenance and waning phases.

The debate around economic consequences that occurs later in an environmental issue life-cycle may be the cause of an environmental issue's perceived 'waning'. It is worth asking whether an environmental issue life-cycle reflects the issue's actual resolution via action and public policy, or whether an issue life-cycle actually serves to 'phase' an issue out of public attention. Part of what dissolves an environmental issue is the treatment of it during these later phases of the life-cycle as a different type of issue other than environmental, such as a policy, energy, science or technology story (Hansen, 2010: 14). This has the effect of dissolving the political discussion of the environmental problem (Hansen, 2010: 14). Hannigan (2006) suggests that environmental problems, as socially constructed issues, do not rise and fall on their own, but are heavily influenced by the rhetorical claims-making processes of governments, environmentalists, citizens, corporations, industries and journalists (p. 63)

\subsection{Manufacturing uncertainty of environmental science}

One of the most influential ways that environmental news coverage influences environmental policy is through its treatment of environmental science. For environmental issues in particular, the framing of science impacts public understanding of the issues (Boykoff, 2009: 443). This section shows how news media manufacture uncertainty of environmental science to aid the legitimacy claims-making of powerful actors.

Science is the most commonly accepted method of acquiring knowledge about nature, understanding environmental problems and coming up with solutions to these problems. Much of environmental discourse has become bound in scientific language (Lash et al., 1996: 1). Science is a frame for truth on the environment that 
goes unquestioned not only by journalists but by most academic critics of environmental discourse. Science gets symbolically legitimised as the main authoritative source of environmental knowledge (Cox, 2006: 333). Preserving science's authority can serve to stabilise current political and economic systems by allowing aspects of environmental issues to be left out of environmental discourse. Tim Forsyth (2008) argues that the environmental debate is compromised when the implicit political implications that underlie many scientific discourses on the environment are not acknowledged (pp. 27-38).

Science is relied on to identify cause and blame in cases of environmental pollution. The scientific authority on environmental problems places science at the heated centre of contention within accountability conflicts, and industry groups and corporations try to deflect blame by proving that scientific findings are uncertain. Hays' (2000) historical account of the treatment of environmental science reveals that since the onset of environmentalism in the mid-twentieth century, every environmental scientific development has been a source of controversy and opposition. To an extent, this is due to some disagreement among scientists themselves, but for the most part controversy occurred because of the recommendations the science had for policy and businesses (Hays, 2000: 138). Constant controversy in the field of environmental science has developed an accompanying discourse of suspicion, doubt and uncertainty (Hays, 2000: 138). Cox argues that this trope of uncertainty about science in environmental discourse is maintained as a political tactic that often ends up delaying or deterring environmental action and policy (2006: 344). The trope of uncertainty has been maintained throughout history in part through the recurrent labeling of science by various actors, including those within the scientific community, as either "good" or "bad", or as "flawed" or "junk" science (Hays, 2000: 138-40). The conflict can also take on the form of intensely personal attacks on individual scientists (Hays, 2000: 150).

The trope of uncertainty is used as a political tactic by industries to aid legitimacy claims-making. In 'Manufacturing doubt: journalists' roles and the construction of ignorance in a scientific controversy", Stocking and Holstein (2009) situate scientific 
uncertainty in a politics of knowledge, and argue that scientific ignorance is socially and intentionally constructed by powerful actors making legitimacy claims (p. 25). Cox describes industry-sponsored attempts to cast doubt on environmental science, some of which include multi-million dollar investments to promote research that will discredit existing environmental science (2006: 347).

The trope of uncertainty creates a need to achieve absolute scientific certainty in order to justify political action. While environmental action is required immediately to preserve global ecosystems, there is an increasing demand for conclusive proof and 'perfect' knowledge on every environmental topic before initiating solutions (Cox, 2006: 337). Where there are gaps in scientific environmental research, vested interests are better able to manipulate data, and deflect blame (Cox, 2006; Beder, 1997). At the same time, Boykoff (2008) argues that even when there is a greater understanding on a topic through multiple research projects, slightly varying conclusions can get pitted against each other despite general agreement between scientists (p. 42).

Scientists must specify aspects of their claims they are not certain about, which can further serve industry and business legitimacy claims-makers. Scientists are now required to "specify ignorance" (Stocking and Holstein, 2009: 23). That is, they are required to state the specific areas of knowledge claims that they are not fully certain of. However, specifying ignorance can subject scientists to criticism (Hannigan, 2006: 98). These statements of doubt can then be used against the scientist to discredit their findings. Presenting environmental science, whether it aligns with a consensus or challenges existing knowledge, can be a lose-lose situation for scientists and environmentalists, and a win for industries evading accountability.

It is important to remember that science is in essence indeterminate and uncertain. It can never explain cause and effect with complete certainty, nor can it be expected to provide an exhaustive survey of all the environmental issues that may exist, or calculate their exact severity (Cox, 2006: 333; Hannigan, 2006: 97). Hannigan (2006), Cox (2006) and Wynne (1996) all support the application of the precautionary principle in environmental science. This is the idea that if there is 
any evidence at all pointing to the possibility of human-caused environmental harm, even without certainty of fact, action should be taken to try to eliminate or reduce this damage, because by the time scientific certainty is reached, if it is reached at all, it may be too late (Hannigan, 2006: 97).

There is a need for the public to better understand how ignorance is manufactured and socially constructed in environmental discourse. This includes developing a better understanding of the power dynamics at play between producers of knowledge and those making legitimacy claims in public discourse (Stocking and Holstein, 2009: 24). Environmental issues must not only be seen as problems for scientists, but also as political issues.

\subsection{Summary}

There is an ongoing tension in environmental discourse between the Dominant Social Paradigm and the New Environmental Paradigm that exposes the limits to economic growth. Environmentalism initially emerged as a counter-discourse that challenged dominant assumptions of unlimited growth and Earth as an abundant resource. Assumptions about the inherent good in the pursuit of economic growth are contained in the Dominant Social Paradigm. Environmental problems that are brought to public attention serve as challenging reminders of the consequences to economic growth, development and trade. Systematic harm done to the environment is a legalised hazard of global production and consumption processes as part of technologically advanced industrial societies. The global economic system of development, growth and trade hinges on exploiting the environment's 'resources' for its production, consumption and disposal of waste.

An open debate is required in the public sphere to address the economic/environmental paradigmatic tension politically. The public sphere is a discursive arena where public opinion is formed and expressed, and public policy is debated. Obtaining democratic discussion in the public sphere requires transparency about environmental problems, their causes, and their context within political and economic systems. News media are the primary source of information about environmental problems and politics in the public sphere. News media 
discourse is central to shaping the public's beliefs, attitudes and perceptions of environmental issues. News media not only provide information about environmental science and politics, but frame information in a way that shapes how the public perceives it. One of the barriers to news media providing democratic transparency is that the survival of media institutions depends on a political environment they both operate in and influence. Media discourse is influenced by a media political economy through everyday journalistic micro-processes such as covering environmental stories as one-off events, presenting 'balanced' coverage, dramatizing news stories to capture interest, and relying on a shortlist of professional sources. The economics of news production largely influences which environmental problems are communicated to the public and how they are presented.

Media discourse is also influenced by macro-power relations between media institutions and their corporate partners and shareholders. News media institutions stabilise dominant discourses by repeatedly framing stories in ways that legitimise the claims of powerful actors. Environmental news discourse is dominated by legitimacy claims-making. News media aid powerful actors in their symbolic legitimacy claims, and in doing so aid those who oppose environmental action by maintaining their preferred invisibility.

News media also aid the environmental opposition by sustaining a trope of uncertainty around environmental science. Science sits at the core of influence on public decisions about the environment. It is, therefore, important to ensure that the scientific knowledge reported in the news is just and free of manipulation or political influence. However, by situating scientific knowledge within frames that serve legitimacy claims-makers, science gets either credited or discredited according to the claims-makers, and not according to its credibility among the scientific community. Uncertainties are used in legitimacy claims-making, particularly in the area of industries opposing governmental regulation. The trope of uncertainty delays policy with demands for more science, but the cycle of casting doubt on new science is bound to continue unless the public can be brought to a better understanding of the ways in which scientific knowledge is politically manipulated by powerful legitimacy claims-makers who dominate the discourse on the environment. 
The influence of the political economy on news media production is explained by Eder's (1996) description of the public sphere having turned into a marketplace. In the public-sphere-turned-marketplace, actors must compete to influence media frames and the symbolic packages contained within them. Environmentalism becomes one of the symbolic packages used by powerful actors to leverage their legitimacy claims. While before the 1980s environmentalism was presented in the media as a counter-discourse voiced by environmentalists (the protest actors), it is now voiced by all claims-makers in the discourse. Environmentalism has become mainstream and is no longer treated as counter-discourse that challenges dominant discourses. Eder argues that the transition into post-environmentalism coincides with the transformation of the public sphere into a marketplace.

This thesis is aimed at understanding the influence of political economic systems on media coverage of the environment. I argue that the post-environmental discourse excludes the presence of a counter-discourse to challenge dominant assumptions about the limits to economic growth, development and trade. This is because the discourse is already crowded with voices claiming to be concerned with the cause. However, these voices treat the issue as if it is being sufficiently 'managed' via existing governmental regulation. In the next chapter, I analyse the news discourse around the Save Lake Winnipeg Act. Then, in Chapter Four, I return to the discussion around post-environmentalism and environmental discourse, relating it to my analysis of the news coverage. 


\section{Findings and Analysis: Two Narrative Frames, Two Legitimacy Claims}

\subsection{Introduction}

"We know that we can't afford to cut corners. We know we have to go the full distance to save Lake Winnipeg."

- Manitoba Water Stewardship Minister Christine Melnick, (\#73, see Appendix I for details of all newspaper articles cited)

The above quote is from a newspaper article in the Winnipeg Free Press published on 9 July, 2011. The article announced the province of Manitoba's plans to toughen city waste-water treatment laws as part of the Save Lake Winnipeg Act. The quote, from a speech by Manitoba Water Stewardship Minister, highlights a sentiment expressed by politicians throughout the news coverage that Lake Winnipeg must be saved no matter what the cost. This quote is an example what I call the Save Lake Winnipeg rhetorical motif. Rhetorical motifs, as described by Hannigan (2006), are used to attribute moral significance to actors claiming to support the environmental cause (p. 65). The Save Lake Winnipeg rhetorical motif reflects a message communicated throughout the coverage that the lake is in need of saving. I show that the Save Lake Winnipeg rhetorical motif is used by the provincial government, the City of Winnipeg and the hog industry. The shared voicing of the Save Lake Winnipeg rhetorical motif shows that it is a strong symbolic asset used in the discourse to aid legitimacy claims-making.

In this chapter, I conduct a discourse analysis of the news coverage of the Save Lake Winnipeg Act and related political debate. The Save Lake Winnipeg Act was a bill passed by the Manitoban provincial government in June 2011. The policy changes included in the Act focused on three areas: renovation of the City of Winnipeg sewage treatment systems, preserving wetlands throughout Manitoba, and new environmental regulations for agriculture, particularly the hog industry. In my 
analysis I find that two conflicts emerge in the news coverage of the new regulations - the nitrogen debate and blaming hog farmers. These two conflicts are constructed narrative frames, as described by Cox (2006: 186-8), because they organise the issues into recurrent stories involving a protagonist and an antagonist. The first narrative frame - the nitrogen debate - encompasses the legitimacy claim made by the City of Winnipeg (protagonist) in an effort to negotiate the regulations introduced in the Save Lake Winnipeg Act by the provincial government (antagonist). The second narrative frame-blaming hog farmers - encompasses the legitimacy claim of the large-scale hog industry (protagonist) that rejects industry regulations in the Save Lake Winnipeg Act introduced by the government (antagonist).

In section 3.2, I discuss the historical and political background of the Save Lake Winnipeg Act. In section 3.3, I describe the Save Lake Winnipeg rhetorical motif used throughout the news coverage, and discuss why it is considered such a strong symbolic 'asset' for legitimacy claims-making. In sections 3.4 and 3.5, I draw on citations from the Winnipeg Free Press news coverage to demonstrate how each narrative frame is constructed by journalists, and how the Save Lake Winnipeg rhetorical motif recurs throughout the two conflicts. I critically discuss the contextual significance of each conflict, using my three 'lenses' described in Chapter One - the influence of media framing, the treatment of science, and the influence of the Dominant Social Paradigm on the discourse.

\subsection{The Save Lake Winnipeg Act}

Lake Winnipeg's ecology has been under-studied compared to other lakes in Canada (LWIC, 2005). This is partly due to logistics (poor road infrastructure surrounds the lake), and also partly due to a limited research season, since the lake is frozen for seven months of the year, typically from early November to early June (Evans, 2000: 74). The lake is also under-studied because it was assumed up until recently that the lake was remote and, therefore, not substantially impacted by human activity (LWIC, 2005: p.52). 
In 2005 the Lake Winnipeg Implementation Committee (LWIC), a nongovernmental organization committed to implementing efforts across the watershed to improve the state of Lake Winnipeg, produced a summary report on the current scientific research outlaying the state of Lake Winnipeg. The LWIC were critical of Canada and Manitoba governments for their lack of research funding initiatives for the lake up to the mid-1990s (p. 55). There are still gaps in the knowledge of the lake's changing ecology, but studies have become more frequent since significant changes to the lake have been observed (Evans, 2000: 69). In 2005 Environment Canada, Canada's national department for the environment announced funding of \$1.1 million a year to monitor the water quality of Lake Winnipeg. This is ten times more than what the Canadian government had been contributing in the past toward Lake Winnipeg research, and is the largest amount contributed to any Canadian lake outside of the eastern Great Lakes (LWIC, 2005: 65). In 2008 Environment Canada agreed to contribute another \$17.7 million over four years to conduct initiatives to clean up Lake Winnipeg, including reducing blue-green algae blooms, making the lake more sustainable for tourism, recreation and fishery industries, and generally restoring the ecological integrity of the lake (EC, 2011).

Despite some varying conclusions, there is general agreement in the research as to what activities in the Lake Winnipeg Watershed contribute to the excess phosphorus and nitrogen entering the lake. A report was published in 2011 by Peter Leavitt of the University of Regina and a team of scientists on the state of the lake. The report was commissioned by the University of Regina as well as the Manitoba Government and the Canadian national government. Previously, research on the lake had reported that hog farming contributed 32 per cent of the phosphorus that entered the lake (LWSB, 2006). Leavitt et al.'s (2011) report was controversial because it attributed 50 per cent of the phosphorus as coming from hog agricultural waste (\#51). Peter et al's (2011) report also concluded that 10 per cent of the excess nutrients in Lake Winnipeg was caused by City of Winnipeg sewage.

In addition to phosphorus from sewage, the LWIC report (2005) stated that the City of Winnipeg's drinking water systems produce 200 tonnes per year of phosphorus through phosphoric acid that is added to drinking water to reduce lead levels, of 
which 50 to 60 tonnes per year is estimated to end up in Lake Winnipeg (p. 41). In 2003 the Clean Environment Commission recommended that the City of Winnipeg develop a plan to remove phosphorus and nitrogen from wastewater, with a priority placed on phosphorus (in LWIC, 2005: 41). According to Clean Environment Commission's report, this is because algae are capable of picking up nitrogen from the atmosphere once there is already an excess of phosphorus (LWIC, 2005: 41). Global climate change has affected the lake's algae blooms as well. Algal blooms have increased in years where temperatures are higher than normal, such as in 2005 and 2010, which had the highest global temperatures on record (EC, 2011: 3).

The loss of wetlands in Manitoba has contributed to the increased levels of nutrients found in Lake Winnipeg. Wetlands are important to water ecosystems because they act as a natural filter of the contents of river water before the water enters lakes. Wetlands cover an estimated 43 per cent of the province of Manitoba (LWIC, 2005: 14). Agricultural activity in the region has led to a loss of wetlands surrounding Lake Winnipeg, as this land has been converted for agricultural use. With the loss of wetlands, agricultural runoff flows into the lake at a faster rate. Lake regulation by Manitoba Hydro for hydroelectricity also contributes to the loss and alteration of wetlands surrounding the lake (LWIC, 2005: 45). Wetlands are also threatened by global climate change (LWIC, 2005: 14).

Efforts have been made by the Government of Canada, Manitoba Government and non-governmental organizations to help fund research, raise awareness, and introduce legislation to protect Lake Winnipeg. This includes Manitoba-based organisations such as the Lake Winnipeg Stewardship Board, Lake Winnipeg Foundation, Lake Winnipeg Implementation Committee and Manitoba Wildlands. International bodies that have contributed to raising awareness of the lake include the International Lake Environment Committee, International Joint Commission (a jointly US-Canada government funded organization which represents the Red River Basin on US-Canada issues relating to the red river basin), Red River Basin Commission (an independent charity devoted to community-based educational and outreach programmes), and the International Water Institute (a US-Canada jointly 
funded institute which conducts research on the Red River Basin) (LWIC, 2005: 634).

The Save Lake Winnipeg Act was introduced in June 2011. It followed the release of Leavitt et al.'s (2011) report concluding that the main contributors to phosphorus and nitrogen into the lake were the hog industry, City of Winnipeg and the loss of wetlands across the province. Before the Act, hog farmers had been monitored by regulations and were subject to inspections and reviews, but enforcement and compliance on these regulations was inadequate (Novek, 2003). The Save Lake Winnipeg Act turned the regulations into provincial law. In an attempt to reduce the amount of phosphorus and nitrogen entering Lake Winnipeg, the Save Lake Winnipeg Act included:

a) A ban on future hog industry expansion for farms that do not use advanced water protection practices

b) A ban on future hog industry expansion in certain parts of the province (some parts of the province already had an existing ban where hog farms were not permitted (Novek, 2003))

c) A ban on "winter spreading" starting in 2013 (the practice of spreading manure over fields during the winter season)

d) Tax credits for hog farms that comply with advanced environmental practice (Manitoba Bills, 2011).

The Save Lake Winnipeg Act also required the City of Winnipeg to build new sewage treatment plants that would filter phosphorus and nitrogen out of city waste before it entered the Lake Winnipeg Watershed via the Red River (Manitoba Bills, 2011). Saving wetlands was the third feature of the Save Lake Winnipeg Act along with city sewage and hog industry regulations, but there was no conflict sparked by this in the news coverage, perhaps because it did not directly impact an industry or corporate body. I have, therefore, chosen to remove the discussion around wetlands preservation from my analysis.

During the week of 18 June, 2011, the Save Lake Winnipeg Act was passed in the Manitoba legislature by the governing New Democrat Party (NDP) with unexpected 
unanimous support from the Progressive Conservative Party (PC) opposition. An editorial article by political analyst Dan Lett (\#67) was published that examined the PC party's motivation for passing a bill. Lett suggested that the PC party passed the bill so that the party would not have to oppose it as an election issue, as the PC party might have deemed Lake Winnipeg too difficult a cause to argue against. The hog industry, as part of the environmental opposition described by Hays (2000), noted their preferred invisibility by not showing up to the public hearings. It could be argued that their preferred invisibility helped the passing of the Save Lake Winnipeg Act. However, Hays (2000) stated that usually, the environmental opposition conducts politics through subtle or secretive means. There is, thus, reason for suspicion that the hog industry will proceed to influence the legislation to their advantage in ways that will go overlooked by the news media.

\subsection{Saving Lake Winnipeg}

The 'Save Lake Winnipeg' phrase first appears in the name of the Save Lake Winnipeg Act itself. The name of the Act does more than simply describe - it communicates a rhetorical message. Naming the Act the Save Lake Winnipeg Act can be seen as what Cox (2006) describes as a "constitutive rhetorical force" (p. 58). The name implies that the lake is in need of saving, is worth saving, and that the saving will occur with the governmental legislation. Similarly, the 'Save Lake Winnipeg' phrase is a rhetorical motif, as described by Hannigan (2006), because it is used to attribute moral significance to those who use the phrase. The Save Lake Winnipeg rhetorical motif is repeated throughout the news articles with the use of other phrases as well, such as "clean up Lake Winnipeg" (\#63). Examples of the Save Lake Winnipeg rhetorical motif being repeated by journalists include the following:

"Faced with a warning that Lake Winnipeg could be rendered a toxic pool, the province vowed Tuesday to fast-track a strategy to save it.” (\#51)

"Clean up Lake Winnipeg: There have been several reports about the ailing lake, and the province has launched several rounds of lake-saving initiatives" (\#63) 
"In the march to save Lake Winnipeg, the provincial government has put Winnipeg taxpayers on the hook for a controversial, expensive upgrade to the North End wastewater treatment plant." (\#97)

“Troubled Lake Winnipeg may have a new saviour” (\#69)

One reason why the Save Lake Winnipeg rhetorical motif is so strong is because lake and cottage life are important aspects of Manitoban culture, and is also part of wider Canadian nationalistic narratives. Manitobans culturally associate the lake with summer, holidays, cottages, beaches, fishing, canoeing and childhood. The following quotes come from Manitobans expressing a deep-rooted childhood connection to Lake Winnipeg and the cultural significance they hold to it:

"A couple of years ago, I was walking with my son along one of the beaches at Victoria Beach [a cottage area on Lake Winnipeg], and we went into the water and came out covered, up to his neck, in green goop... It was caked on. I thought, 'we're not going in there anymore,' and made myself a promise that I was going to look into it. We've always had a cottage, I've been going to that neck of the woods - either Victoria Beach or Albert Beach - for coming up on 40 years of my life, and I'm 41 now. I remember, when I was growing up, canoeing in that water, even drinking the water, and never thinking too much about the water quality."

- "Paul Kemp, filmmaker of Save My Lake (David Suzuki documentary)

"When Karen Boyd [president of the Lake Winnipeg Foundation] looks out at the waters near her home at Victoria Beach she sees a troubled lake. 'It used to be you would get the pea-soup algae in August, but then you would see it earlier and earlier,' Boyd said recently. 'Then we started seeing the blue-green stuff... it has been 10 years since we moved up here temporarily. I've seen the changes that have happened to the lake. It's a real concern. I'd like to see our children and our grandchildren enjoying the pleasures we have here." (\#48)

"I spent my early summers at Victoria Beach, and while I've long since opted for the lakes of northwest Ontario, those childhood memories remain deeply meaningful to me. Watching the decimation of the once-pristine beaches of Victoria Beach is both disheartening and sickening to anyone who stands by the belief that our lakes, parks and natural habitats belong to all of us, and hence the protection of them is a responsibility no one ought to shirk." 
There has been an increased awareness of Lake Winnipeg's blue-green algae outbreaks since 2003. This is, in part, due to successful media claims and new government policies, such as regulations issued by the Manitoba Government that began in 2003 (\#9). Additionally, in April 2011, Canadian celebrity and environmental spokesperson David Suzuki released a documentary on the problems with the algae on Lake Winnipeg (\#29). These factors all contributed to an increased public awareness that the algae blooms, caused by an excess of phosphorus pollution entering the lake, were a significant environmental problem.

It is not only the algae problem that has received recent media attention - Lake Winnipeg faces multiple environmental problems, and many of these have successfully made the news in the last decade. These issues are often discussed together and alongside the algae issue, so there is a possible effect of the issues mutually influencing each other in increasing public concern. Other lake issues that appeared in the news in 2011 included:

- Manitoba Hydro's regulation of the lake's water levels - Manitoba Hydro generates hydroelectricity by regulating the lake's water levels. In December 2010, Manitoba Hydro applied for a permit from the Manitoba provincial government which would grant them a permanent license to regulate water levels (Manitoba Wildlands, 2012). A public hearing is currently taking place for consideration of a Manitoba Hydro permanent license.

- Shore erosion - although erosion is a common natural occurrence on Lake Winnipeg due to its volatile water levels, erosion has also been increasingly caused by storms and hurricanes that have grown in intensity as a result of global climate change (LWIC, 2005: 45-51). Damage to beaches and properties on Lake Winnipeg, due to erosion caused by a hurricane in October 2010, received news coverage throughout the first few months of 2011.

- E. coli - Escherichia coli (E. coli) is a bacterium that can cause damage to human and non-human animal health when exposed in large numbers. E. coli levels have "occasionally exceeded" healthy levels on Lake Winnipeg's 
beaches, according to the Environment Canada report (2011: 12). Cases get reported every summer of beaches needing to be closed for recreational use due to high E. coli levels found in the water, making it unsafe for swimming.

- Harmful chemicals - besides phosphorus and nitrogen, other harmful chemicals, pharmaceuticals and personal care products have entered the lake through agricultural runoff and sewage (LWIC, 2005: 45-51).

- Invasive foreign species - at least eight invasive foreign species have been found in the lake, threatening the lake's ecosystem (LWIC, 2005: 45-51).

- Endangered species - at least six species of aquatic life native to the lake have been declared endangered or threatened (LWIC, 2005: 45-51).

Another factor in the strength of the 'Save Lake Winnipeg' phrase used as a rhetorical motif is that in April 2011 Manitoba suffered a flood that caused a significant loss of property - one article described it as "among the worst Manitoba has ever seen" (\#50). The flood issue may have compounded the perceived severity of the lake's issues in a mutually reinforcing way, since the two issues were often mentioned together in the discourse. Manitoba is a low-lying province naturally prone to spring flooding. Flooding has increased in the region over recent years due to human causes such as global climate change, and the loss of 70 per cent of the province's wetlands through converting land for agricultural use. If this land had not been converted, it was reported that the wetlands would have held some of the water and prevented some of the flooding the region (\#50).

Manitoba's 2011 flood contributed to an increased awareness of how environmental problems affect individuals directly, and this is evidenced in the news discourse. Josh Brandon, water caucus coordinator at the Manitoba Eco-Network (a local nongovernmental organization), related the flood experience of Manitobans to a larger ecological discourse on global warming. He stated,

"The effects of global warming are already stretching communities across the planet to the breaking point. We share global environmental problems that threaten everyone. Just as we come together to build dikes and fill sandbags to protect our neighbours, we must all work together to solve this environmental crisis before it floods us all." (\#50) 
This quote shows evidence of the flood being associated with a global discourse of environmental concern. Another example comes from an article ending with the following paragraph:

"More than a century of settlement and agriculture in southern Manitoba has dramatically altered the lay and life of the land. But nature, as has been seen in spades this spring, has a way of reasserting its domination. There are better ways of living in concert, but Manitobans must accept that it will cost everyone money to get to a careful balance that protects not just the Big Lake but the smaller bodies of water, the homeowners, cottage dwellers, farmers and wildlife." (\#57)

The reference to nature's "domination" in this article could be evidence that the flood served to alert the Manitoban public of a need to better manage Manitoba's water ecosystems.

Another reason to explain the strength of the Save Lake Winnipeg rhetorical motif is that 2011 marked an election year for the province. Lake Winnipeg was one of the central issues debated in the 2011 election campaign (\#63; \#80; \#100). Environmental problems have increasingly become important platforms on which to conduct electioneering, according to Mühlhäusler and Peace (2006: 461). The year 2011 featured a provincial political dynamic that was accommodating to environmental issues already, due to the existing left-wing majority government. A majority New Democrat Party (NDP) provincial government was in place in Manitoba throughout 2011. The NDP tend to focus strongly on issues such as health care and the environment.

Lake Winnipeg was also used by the Progressive Conservative (PC) party during their 2011 provincial election campaign. Article \#107 describes a speech by PC candidate Hugh McFadyen on the Lake Winnipeg issue. The article opens by describing McFadyen next to a pond of Canada geese - a symbolic choice of location associating McFadyen with environmental concern. McFadyen announced during his speech that if elected, his party would "help clean up Lake Winnipeg" by maintaining some of the laws contained in the Save Lake Winnipeg Act, such as the laws aimed at preserving provincial wetlands. It is not clear whether the election coverage of the lake contributed to the heightened intensity of the issue, or whether it 
reflected an already existing public concern that the candidates were appealing to, or both. However, the fact that McFadyen incorporated a plan to address lake issues into his campaign further shows how important the cause was during the provincial 2011 campaign.

The strong public concern for Lake Winnipeg means that the Save Lake Winnipeg rhetorical motif is a strong 'symbolic asset', as described by Eder (1996), in legitimacy claims-making. The term is loaded with moral significance due to the growing public concern for Lake Winnipeg, and global environmental issues in general, for Manitobans.

\subsection{The nitrogen debate}

\subsubsection{The story}

During January to June 2011, when the Save Lake Winnipeg Act was introduced by the Manitoba Government, a debate was sparked in the news between the Manitoba Government and the City of Winnipeg. The debate centred around one of the Act's new laws forcing the city to build new sewage treatment facilities to prevent phosphorus and nitrogen from entering Lake Winnipeg (\#9). The province supported the law with Leavitt et al. (2011)'s scientific report that attributed 10 per cent of the phosphorous and nitrogen in the lake to the City's waste disposal (\#54).

A conflict of accountability discourse, as described by Beck (1996), emerged in the news coverage between the Manitoba Government and the City. The City of Winnipeg, a city with a population of around 700,000, accepted the need to build a new sewage treatment plant to filter phosphorus. However, they refused to build treatment facilities to filter nitrogen because their scientific sources informed them that it was not necessary to do so to protect Lake Winnipeg. The science cited by the city indicated that, although it was necessary to treat sewage for phosphorous to reduce algae blooms, it was pointless to spend the extra cost of treating the sewage for nitrogen (\#12). According to the City's science, although algae thrive in phosphorous- and nitrogen-rich water, reducing nitrogen in the lake would have no effect on reducing algae blooms because nitrogen is an abundant element in the 
Earth's atmosphere, and so algae can extract nitrogen from the air even when there is less of it in the water $(\# \mathbf{5 6})$.

The city presented a public campaign to explain why they were resisting the province's laws forcing them to filter nitrogen. As a result of City campaigning that it was a waste of public money to treat its waste for nitrogen, the province agreed to allow the city to build new sewage treatment plants that only treated the sewage for phosphorous, and nitrogen only in the form of ammonia (as ammonia is known to be harmful to fish and other aquatic life). The province, however, stated that they reserved the right to enforce the city to treat their waste for nitrogen in the future, should science later provide evidence that this would help prevent the lake from experiencing toxic algae blooms (\#57).

\subsubsection{The nitrogen debate as a narrative frame}

The case made by the city in protest of the province's new laws is an example of legitimacy claims making as described by Cox (2006). Cox described the process through which actors gain legitimacy for opposing environmental regulation as distinctly rhetorical - that is, symbolic messages are used to convince the public of their claim (2006: 338). Throughout the nitrogen debate, the City attempted to earn their legitimacy to reject the provincial law. The news coverage of the nitrogen debate aided the City of Winnipeg in their claim for symbolic legitimacy in two ways: first by dramatising the story and framing it as a conflicting debate to capture interest, and second by portraying the city as the righteous protagonist and the province as the antagonist.

The news journalists framed the story as a conflict through selective language. Headlines such as "Nitrogen debate wastes time, money" (\#54) and "Foolish water wars" (\#15) served to dramatise the story and ignite a sense of conflict. These headlines also conveyed that the two governments were bickering "foolishly" over the technical details of managing the Lake Winnipeg problem. Yet, another message was simultaneously conveyed that the debate was important enough to potentially save the public a significant expense. The following example shows the language used by the newspaper to construct the conflict: 
"The province and the city are colliding once again on the subject of waste-water treatment, a fender-bender that could cost the taxpayer millions of dollars in needless spending and further damage the civicprovincial relationship." (\#15)

The nitrogen debate narrative frame antagonised the province's actions as "wrong" and "unnecessary":

"Common sense has eluded the decision-makers on Broadway [the street address of the Manitoba Government building]” (\#15)

"Forcing Winnipeggers to pay $\$ 350$ million for unnecessary technology in a sewage plant when so many other infrastructural needs go unmet is simply wrong” (\#53)

By constructing the narrative frame in this way, the news coverage aided Winnipeg mayor Sam Katz as he attempted to gain legitimacy by appealing to a public's value for "common sense" and scientific reasoning. Common sense can be one of the acts of legitimation called upon, according to Cox (2006: 60). Cox explains that symbolic legitimacy boundaries are used to place an actor inside the symbolic boundary and others outside it (2006: 61). The labeling of the province as lacking in common sense was an attempt to place the province outside of the symbolic legitimacy boundary of good reasoning.

\subsubsection{Science and the nitrogen debate}

Science is the focal point of the nitrogen debate. Scientific research is the basis on which the province created the Save Lake Winnipeg Act; science informed the province that the algae blooms were caused by an excess of phosphorus and nitrogen in the lake. Science also informed the City of Winnipeg that it would not make a difference to the lake to filter nitrogen as well as phosphorus out of the city's sewage waste. During the nitrogen debate, one article (\#53) featured a comparison between two scientists on the issue - one arguing that nitrogen must be controlled from entering the lake, and one arguing that this is not necessary to reduce the algae problem in Lake Winnipeg. In another article (\#54), scientist David Schindler explained the science behind the city's position in detail. 
The story was framed so that the science was the central point of contention in the nitrogen debate. The language in the articles conveyed the message that the science behind both governments' positions was the topic of debate:

"I've made it clear where science stands on the issue"

- Winnipeg Mayor Sam Katz (\#9)

"The standards should be set by science" (\#15)

"Pivotal work done by Winnipeg scientists should be trusted” (\#54)

"Dozens of freshwater scientists presented formidable evidence that cutting nitrogen is not only financially wasteful but potentially damaging." (\#57)

"The Selinger government decided to bow to the weight of scientific evidence that phosphorus, not nitrogen, is the culprit in the rapid growth of blue-green algae choking Lake Winnipeg." (\#97)

The newspaper framed the story with the city as the protagonist, and used the city's alignment with scientific reasoning to justify this. The city's reliance on the science to justify their claims attributed moral significance to the city's argument and furthered their claim for legitimacy.

\subsubsection{The nitrogen debate and a negotiation of cost}

The nitrogen debate features two governments disputing science as central, but there is also a conflict over the cost of the environmental regulations. Throughout the coverage, the ecological benefits (and consequences) and economic consequences (and benefits) are weighed out and negotiated. One article states:

"City officials say the daily limits are overly restrictive and will cost an additional \$60 million for 'no measurable' environmental benefit.” (\#12)

There appears to be no trend in the articles for listing either economic and ecological benefits or costs first. For example, in article \#9 the economic costs of the new sewage treatment regulations are given, followed by the ecological benefits:

"In 2003, the province ordered the city to build the nutrient-removal facility as part of a larger waste water treatment upgrade that will eventually cost the city billions. 
The province wants the facility to remove both phosphorus and nitrogen, which promote the growth of algae that cloud Lake Winnipeg during the summer, then die off in large quantities, depriving the lake of oxygen."

These examples show a negotiation between environmental and economic costs and benefits. The examples of cost-benefit analysis used to assess the Save Lake Winnipeg Act regulations align with patterns described by Hays (2000) as part of a history of environmental opposition discourse (p. 155).

The actual additional civil spending required to filter nitrogen from the city's sewage, when the city was already building new treatment plants to filter phosphorus, differed considerably throughout the news coverage. In article \#12 (February 2011) mayor Sam Katz was quoted as saying the nitrogen removal alone would cost \$60 million, but article \#56 (June 2011) quoted provincial officials as saying that the city's figure was inflated, and that the actual cost of removing nitrogen would be around \$33 million. Later, article \#97 (September 2011) reported that the total cost of removing both nitrogen and phosphorus from city sewage would be $\$ 400$ million, but to remove phosphorus alone would cost only $\$ 50$ million - implying that the cost to filter nitrogen would be $\$ 350$ million. It is difficult to say whether the differently quoted costs were deliberate attempts by the city to further bewilder a public audience or to further delay political decisions. Nevertheless, the inconsistency did not seem to take away from the message the city had for the public, which was that there would be needless money spent should the city comply with the province's new waste treatment law.

Here is another example of a discussion around whether sewage treatment is worth the cost:

"What Winnipeg really needs is to know what the best science says about the impact of pollutants in effluent, and specifically whether, now, ammonia really is the toxin to fish the province - based on another jurisdiction's say-so - is presenting it to be. Then Winnipeggers can decide if a $\$ 400$ million wastewater treatment system is worth paying for." (\#97)

This quote reveals an underlying shared understanding of how environmental policy is and should be informed. The quote implies that the expected process of 
environmental policy-making goes like this: first science will provide conclusive evidence that shows the best possible action to protect the environment (for example, to save the lake). Science will then determine how much it will cost to implement this action. A negotiation of cost is found here in the discourse, but the science remains the deciding factor.

\subsubsection{The Save Lake Winnipeg rhetorical motif in the nitrogen debate}

The Save Lake Winnipeg rhetorical motif is an important commonly held value used to further the city's legitimacy. Here are some examples:

"These spurious claims have unnecessarily delayed policies to protect and restore the lake."

- David Schindler, scientist supporting the city (\#54)

"To spend \$350 million would not only be flushing good money down the toilet, you'd also be doing more damage to the lake"

- Winnipeg Mayor Sam Katz (\#56)

The first quote is from an article (\#54), written by scientist David Schindler of the Experimental Lakes Project, and published in the Winnipeg Free Press, supporting the science used by the City of Winnipeg. The "spurious claims" to which Schindler refers are the scientific claims used by the provincial government that deemed it necessary to filter nitrogen from the city's sewage. The second quote is from Winnipeg Mayor Sam Katz opposing the province's law, by saying that treating city waste for nitrogen would not only be unnecessary, it would further harm the lake. The Save Lake Winnipeg rhetorical motif is being carried through the city's rhetoric showing that, despite opposing the law to treat waste for nitrogen, the City still supports the idea of 'saving' the lake.

So far I have shown that the news journalists framed the nitrogen debate as a conflict-ridden narrative, with differing science as the focal point of the debate, but also involving a weighing out of the cost of environmental regulation with its the ecological benefits. I have shown that the City of Winnipeg benefited from the journalistic framing because it aided their legitimacy claim alter parts of the new regulations. The city also used the Save Lake Winnipeg rhetorical motif throughout the nitrogen debate to further their symbolic legitimacy claim. I have 
shown that the coverage of the city sewage aspect of the Save Lake Winnipeg Act was dominated by the City's legitimacy claim. The Save Lake Winnipeg rhetorical motif was the central symbolic asset used, but the science was also used as a symbolic asset to attribute moral significance to the city's argument.

\subsection{Blaming hog farmers}

"The industry feels unloved and unwanted." (\#19)

The above quote comes from an article reporting that the Manitoba Government gave \$26 million to the Manitoba hog industry, with the explanation that it would "help manure management and reduce the risk of water contamination" (\#19). The quote is part of the second narrative frame I discuss - blaming hog farmers. Through this narrative frame, journalists construct a story of hog farmers, or the Manitoban large-scale hog industry, who claim to be unfairly singled out by the government. The story portrays the hog farmers as being forced by the government to make changes that will be detrimental to their businesses. In this section, I discuss the blaming hog farmers narrative frame and argue that it is used as a rhetorical tool to aid the hog industry in a legitimacy claim for opposing the Save Lake Winnipeg Act.

\subsubsection{The story}

Like the nitrogen debate, the blaming hog farmers story initiated while the Save Lake Winnipeg Act was being publicly debated by the Manitoba Government between January and June 2011. The majority of the coverage transpired during the three weeks leading up the Act passing in June 2011. The news coverage of reactions to the legislation was sympathetic to the hog industry. The hog farmers were portrayed by the coverage as being unfairly singled out by the legislation. The science that informed the Save Lake Winnipeg Act was doubted in the news coverage; different scientific research conducted on the lake was compared that attributed varying proportions of 'blame' on the hog industry for the phosphorus pollution in Lake Winnipeg. 
When the Save Lake Winnipeg Act was passed on 18 June 2011 with unanimous support from all parties in the Manitoba legislature, no representative from the hog industry showed up to the hearing. Political analyst Dan Lett suggested that the PC (conservative) party advised the industry leaders to evade the hearings, on the condition that if the industry supported the party during the next election, the PC party would undo some of the legislation. In his political editorial, Lett states:

"NDP sources claimed this was proof the Tories struck a deal with farmers to stay home and let the bill pass without fuss with the knowledge that (wink-wink, nudge-nudge) all will change in October when there's a new government in town." (\#68)

Lett also theorised that the PC unanimously supported the Save Lake Winnipeg Act so they would not have to campaign around it as a leading election issue. The hog industry's no-show at the public hearing aligns with the tendency, as described by Hays (2000), for the environmental opposition to deliberately maintain invisibility. Perhaps the hog industry preferred to make private deals behind closed doors rather than to openly address their opposition in the public political forum.

The story of the hog farmers being 'singled out' continued in the news coverage throughout the October 2011 provincial election, which was won by the NDP party. The Winnipeg Free Press published an advertisement, funded by the Manitoba Pork Council, in August 2011. The advertisement will be discussed in further detail in section 4.3.5, and is shown in Appendix II. In November 2011, the hog industry indicated in an article (\#102) that they intended to launch a "public education campaign" to inform the public that they had been treated unjustly by the provincial government. It is clear from the coverage throughout 2011, however, that a public campaign had already begun with the aid of Winnipeg Free Press journalists.

\subsection{2 'Blaming hog farmers' as a narrative frame}

The Winnipeg Free Press's coverage of the Save Lake Winnipeg Act aided the hog industry to make a legitimacy claim, as defined by Cox (2006), by constructing the blaming hog farmers narrative frame. The blaming hog farmers narrative frame included the assignment, through the language used in the articles, of an antagonist (the Manitoba Government), and a protagonist (the hog industry). The news 
coverage depicted the hog farmers as being blamed, singled out, and accused unfairly of being responsible for Lake Winnipeg's deteriorating state. The frame was constructed partially by the language used by journalists in the articles as well as in quotes by farmers and industry leaders. The government is antagonised through the portrayal of the government's actions as violent:

"It would not be surprising to see new initiatives targeting agriculture" (\#52)

"The same government ... has already slapped us with a hog barn moratorium in 2008"

- Karl Kynoch, Manitoba Pork Council letter (\#68)

The language used in the articles ("targeting", "slapped us with") constructed an image of the government as resembling an antagonist and the hog industry as the victim of their assault.

A week after Peter Leavitt et al.'s (2011) report was published, Laura Rance, editor of the Manitoba Co-operator (a local agricultural newsletter) contributed an article to the Winnipeg Free Press. Rance's article, repeating the antagonistic language, is cited here:

"Using it [the scientific report] to target the hog industry is both confounding and unfair." (\#62)

"Armed with a new report by Saskatchewan biologist Peter Leavitt that says changing agricultural practices are to blame for at least half of the lake's algae problems, Premier Greg Selinger singled out Manitoba's hog industry as the 'single biggest risk' to the lake and promised tough action." (\#62)

The 'foolish government' trope used in the nitrogen debate is mirrored in the blaming hog farmers narrative frame. During the election coverage, Rance's letter compared the government to an irrational teenager, and as having succumbed to a "fever":

"Any of us who have spent time with teenagers have found ourselves shaking our heads on occasion and asking, 'what were they thinking?' In most cases, they weren't, at least, not with their heads. Apparently, election fever has a similar effect on governing politicians, because that 
very question came to mind while listening to the provincial government's plan to rescue Lake Winnipeg." (\#62)

In the context of the hog farmers making a symbolic legitimacy claim, the "irrational teenagers" and "election fever" references are rhetorical tropes being drawn upon to construct the image of an antagonistic government.

Much of the coverage is told from the perspective of the farmer, assigning emotional states to the farmers, and describing their emotional reactions to hearing about the legislation as being "worried" or "surprised". This perspective is reinforced by emotionally charged interview quotes from the farmers.

"Farmers are worried that the government's response to Leavitt's report may mean intolerable new regulations for their industry”" (\#51)

"Farmers were surprised by the report's conclusions and fearful at how the government will react” (\#51)

"Manitoba hog farmers felt like they had giant targets on their backs" (\#55)

“Hog producers reacted bitterly” (\#55)

"Much of the [government's] new plan rests on discussions with farmers and producer groups, some of which already complain that current controls make it difficult to make a buck." (\#55)

"Crop farmers are now worried, and rightly so, that the province's next step might be to increase regulatory control over synthetic fertilizer use"

- Laura Rance, editor of the Manitoba Co-operator (\#62)

"The portioning of blame was an unpleasant surprise for farmers in this province, who shoulder an even heavier load of the blame for the nutrient loads that originate within Manitoba's borders." (\#93)

"[In addition to the new legislation,] the hog industry has also been hurt by falling hog prices and confounding cross-border regulations" (\#102)

"There are dozens of industries that rely on a productive pork industry. Government doesn't seem to care. I am worried about that."

- Graham Starmer [Manitoba Chambers of Commerce] (\#102) 
The emotive language is particularly strong in the article about the government giving over \$26 million to the hog industry to help them comply with the new regulations:

"The federal and provincial governments are giving hog farmers more than \$26 million to help improve manure management and reduce the risk of water contamination, a cash injection that shows the government has not abandoned the industry, which is still angry about the moratorium on hog-barn expansion in many parts of Manitoba, including the Red River Valley.

The pork industry believe it has been singled out unfairly as the main enemy of Lake Winnipeg, although the City of Winnipeg has been much louder in complaining about the cost it faces in protecting the environment through expensive sewer upgrades. Other industries are also affected by the green agenda and the need to do something about the deteriorating condition of the lake.

Only pig farmers, however, are saddled with a ban on their ability to expand and modernize, while other agricultural sectors are moving ahead without legal restrictions. The industry feels unloved and unwanted, which is not entirely a paranoid delusion, considering the rough ride that was given to a hog-processing plant that wanted to open in St. Boniface several years ago.

...The province has not indicated when, or if, the ban will be lifted, but the recent cash injection is a good step in building a new environmental model for the industry." (\#19)

The story portrayed by the above article is told from the perspective of the hog farmer. This is shown in the description of the farmers as "still angry" and feeling "unloved and unwanted". Describing the financial transaction as a "cash injection" gives the impression that the money was given in a way that resembles a medical treatment being given to an ill patient (the hog industry). In the article, the hog farmers do not merely have environmental regulations placed on them, but they are "saddled with" them. Finally, by saying the \$26 million donation to the industry is a "good step", the article confirms that it is a good idea and is, thus, sympathetic to the hog industry. 
Importantly, the article gives no political context for the decision-making process whereby it was agreed that over $\$ 26$ million of public funds would be given to the hog industry. Nor does the article give an adequate reason to justify the transaction, other than to rhetorically communicate that the hog farmers deserved the funds on moral or emotional grounds - that is, because they have been feeling singled out and victimised. The article does not specify how the money would be spent by the industry, such as whether this money was conditionally given with the expectation or requirement that it would go toward making production practices more environmentally sustainable. Thus, transparency was not adequately achieved in this instance of environmental policy-making.

The idea of the hog farmers being singled out is peculiar given that this narrative occurs simultaneously with the nitrogen debate, within which the city is also being subjected to new regulations. One article that features both issues together still manages to communicate that it is the hog farmers alone who are being singled out. After announcing that the province would give in to the city's requests to cut only phosphorus and not nitrogen in its revitalised sewage treatment plants, the article later states:

"Ultimately, however, cutting 50 per cent of the phosphorus now streaming into Lake Winnipeg will have to focus on agricultural practices, cited recently as the chief culprit in this problem." (\#57)

Despite the City of Winnipeg also having to comply with the province's new laws, the claim is still maintained throughout the coverage that the hog farmers are being singled out as the "chief culprit".

The blaming hog farmers narrative frame is seen not only in the news articles, but in the Have Your Say column of the Winnipeg Free Press - the newspaper's regular section featuring letters to the editor. Responses to the blaming narrative were seen in these letters. The responses were both uncritical of the narrative in that their response related to hog farmers being blamed, and critical of the newspaper coverage on account of it being dishonest or misleading. Here is an example of an uncritical response to the blaming hog farmers narrative frame:

"I am writing in response to the June 3 article 'Hogs blamed for lake woes', which points a finger at the pork production industry as being the 
primary source of phosphorus levels in Lake Winnipeg. It's not the primary source. I would really appreciate it if you would publicize the steps and measures pork producers are taking to clean up their sewage and waste. Enzymes are added to feed to make the phosphorus in the rations highly available. Millions of producers' dollars are being spent on research to find better technology to address the problems that do show up." (\#61)

The perspective of this writer raises the possibility that the blaming hog farmers narrative may have been really experienced by some people. There may have been members of the public who related to the emotions of fear, worry, anger and surprise expressed in the narrative frame. It is difficult to say whether these responses would have been different should the media have framed the story a different way.

On the other hand, here is an example of a letter published in the Have Your Say column that was critical of the blaming hog farmers narrative frame:

"Abusive practice: I take exception to the heading 'Hogs blamed for lake woes ' (June 3). It is not the hogs that are to blame. It is the humans - the farmers who insist on building, expanding and perpetuating a practice that is cruel and abusive to living things and potentially devastating to the larger environment." (\#60)

The response letters published in the Have Your Say column provide an interesting window for viewing the readers' responses to the story, and the particular way it was framed. It is important to remember, however, that the Have Your Say column is also edited by journalists, and these letters are deliberately chosen by editors and, as such, are subject to journalistic narrative framing. Nonetheless, the different responses published in the Have Your Say column reflect that different readers receive and interpret the narrative frame differently, emphasizing that it should not be assumed that readers are a unified audience who passively receive messages in the media. Another example is given in the next section of the use of the Have Your Say column for the journalists constructing the narrative frame.

\subsubsection{The use of science in the blaming hog farmers narrative frame}

Science was treated three ways throughout the blaming hog farmers narrative frame. These included placing science and scientists in the position of the "blamer", 
describing science as "good" or "bad", and comparing the government's science with farmers' lay knowledge. The treatment of the science sustained a trope of uncertainty, as described by Cox (2006), which was used to support the hog industry's legitimacy claim. I compare my findings with Stocking and Holstein's (2009) North Carolina study of a public media controversy in 1999, when industrial hog producers there constructed similar legitimacy claims to oppose similar governmental regulations.

Like in the nitrogen debate, a conflict of accountability discourse took place as part of the blaming hog farmers narrative frame. When the Save Lake Winnipeg Act was passed in June 2011, the newspaper articles in the Winnipeg Free Press used a 'blaming' narrative frame to cover the issue. In some articles, as I have shown, the 'blamer' is the Manitoba Government, but in other articles scientists are depicted as the 'blamers'. In particular, scientist Peter Leavitt, the primary author of the scientific report used to inform the Act, was depicted as the 'blamer' here:

"The study, led by University of Regina biologist Peter Leavitt, recommended that phosphorus levels in the lake be cut in half. He placed most of the blame for rising water levels in the lake on intensive crop and livestock production in Manitoba. 'If you're looking for things that you need to regulate to improve water quality, there's your smoking gun', Leavitt told a news conference Tuesday.” (\#51)

"The Lake Winnipeg report released this week by University of Regina biologist Peter Leavitt, placed at least half the blame for Lake Winnipeg's high-phosphorus problem on crop and livestock farming in Manitoba." (\#52)

There is no denying that Lake Winnipeg is in trouble. It needs our help. But it is important to note the research paper the Leavitt team put together was apparently commissioned to show agriculture is to blame.

- Laura Rance, editor of the Manitoba Co-operator (\#62)

"When freshwater scientists sat down to figure out the source of Lake Winnipeg's ecological problems, farmers wound up with a large portion of the blame." (\#93)

In these quotes, the science is personified as a single individual, Peter Leavitt, despite the fact that Leavitt was just one of the report's seven authors. This is 
contrasted with the coverage of the nitrogen debate which referred more generally to 'the science' or 'scientists'. Focusing on the individual, rather than on a group of scientists, a scientific institution or the general field of science, served two purposes in the context of the 'blaming' narrative frame. First of all, it is easier to claim that an individual is casting 'blame' than to say that an entire institution or field of knowledge is doing so. Secondly, individualising the source of the science made it easier to doubt the science, because an individual can be subject to a greater degree of human error. The opposite was the case for the nitrogen debate, as both the province and the city were relying on science as an authority to legitimate their claims and, therefore, it made sense that the journalists covering the nitrogen debate referred to the science as an institution. In one example, Peter Leavitt's science was accepted:

"There is broad agreement between what Prof. Leavitt has found and the evidence of decades of good science... locally on the lake. That work showed a 50 per cent rise in phosphorus and the resulting growth of pernicious, toxic blue-green algae since the 1990s. That science has spurred dozens of scientists to call for cuts to phosphorus" (\#53)

However, the majority of the articles referred to Leavitt et al.'s (2011) report on the ecological state of Lake Winnipeg as the' blamer' in the narrative frame.

The scientist-as-blamer trope contained within the blaming hog farmers narrative frame can be placed into context of similar tropes constructed by similar legitimacy claims-makers historically. Hays' (2000) historical account of the environmental movement shows that, throughout history, personal attacks on individual scientists have been used as a tactic of opposing environmental regulations (p. 150). Claims of hog farmers being blamed by scientists also occur in Stocking and Holstein's (2009) findings of the media messages portrayed the hog industry regulations in North Carolina in 1999. In the news coverage studied by Stocking and Holstein, individual scientists were conveyed as 'blamers' with a "determination to discredit hog farmers" (2009: 30). Additional charges made by the hog industry in Stocking and Holstein's North Carolina study included labeling the science as biased, incomplete and unwarranted. The message portrayed by the North Carolina news coverage in these instances was that "the scientist, his institution, and collaborators 
were on an unscientific crusade to discredit the hog industry" (Stocking and Holstein, 2009: 32). The media in Stocking and Holstein's case did not only attack scientists, but also their research methods, data, community collaborators and the scientists' universities (2009: 32).

The trope of uncertainty is maintained over the lake science by journalists labeling some of the science as "good", and some as "bad". The two reports being compared throughout the hog farmer story are the 2006 Lake Winnipeg Stewardship Board (a research organization funded by the government of Manitoba) report, which concluded that livestock agriculture was contributing 32 per cent of the excess phosphorus in Lake Winnipeg, and Peter Leavitt et al.'s (2011) report that measured the hog industry's phosphorus contribution at 50 per cent. The Lake Winnipeg Stewardship Board's 2006 report, attributing a lesser percentage of responsibility on hog farmers, was labeled as "good" science in the news articles:

"Chomney, president of KAP [Keystone Agricultural Producers] said the 2006 Lake Winnipeg stewardship report did a good job quantifying the sources of nutrient loading that are plaguing Lake Winnipeg. 'That's the kind of good science we need to continue to do to ensure we make regulatory changes that will benefit the lake. We shouldn't be singling out pork producers, ' Chomney said.” (\#102)

"Agriculture turned out to be the source of no less than 38 per cent of the nitrogen and 32 per cent of phosphorus that originates within Manitoba and winds up in Lake Winnipeg, the stewardship board concluded in its landmark report." (\#93)

Referring to the report as a "landmark report" served to highlight the report's scientific importance. There was no reason or explanation in the articles these quotes were cited in to quantify why this science was "good".

By contrast, the recent 2011 report was referred to as "convoluted science" and "inconclusive":

"At best, singling out scapegoats and combining convoluted science with an election agenda will prove ineffective at restoring Lake Winnipeg to health. At its worst, it distracts and delays actions that will."

- Laura Rance, editor of the Manitoba Co-operator (\#62) 
"The Leavitt report raises some interesting questions about how agriculture interacts with the environment and those questions deserve to be explored. But its findings were not only inconclusive; they are inconsistent with previous research, including the government's own data. The paper needed more scrutiny before forming the basis for public policy."

- Laura Rance, editor of the Manitoba Co-operator (\#62)

The news coverage also featured quotes from hog producers and scientists raising questions of uncertainty around Leavitt et al.'s (2011) report:

"Don Flaten, the Lake Winnipeg Stewardship Board member and the University of Manitoba soil scientist, said Thursday that he has 'some reservations' about Leavitt's study. He said some of the statistical techniques the University of Regina academic used 'don't necessarily prove cause and effect.", (\#55)

"This [Leavitt et al.'s (2011) report] is inconsistent with the scientific evidence that we've been basing decisions on in the past. So I would question the validity of the report",

- Doug Chorney, president of Keystone Agricultural Producers (\#51)

Suppose it were true that the Leavitt et al. (2011) report was "convoluted" in its claim that 50 per cent of the lake's phosphorus was coming from agriculture, and the correct figure was more like the one cited in the LWSB's (2006) report - 32 per cent. To put these figures into perspective, the nitrogen conflict was sparked because the City of Winnipeg was reported to be causing seven to ten per cent of the phosphorus contribution, and yet the city were willing to spend upwards of $\$ 350$ million to contribute to the solution (albeit with some negotiation and resistance as was described in the previous section of this chapter). Therefore, even if the "good" science had been used to inform the Save Lake Winnipeg Act, it would have provided sufficient evidence for the province to issue regulations on an industry clearly causing significant harm to Lake Winnipeg. It is, therefore, clear that the trope of uncertainty around the lake science was constructed, not to inform the public of the actual validity of the science, but to credit or discredit scientific findings according to the hog industry's legitimacy claim. 
The good science/bad science labels resemble a pattern of tactics used by industries to construct doubt in science throughout North America over time. Hays (2000) documents the historical labeling of environmental science as either "good" or "bad" throughout the history of the environmental movement in the United States (pp. 13840). Similarly, Stocking and Holstein's (2009) study showed that the North Carolina hog industry referred to the science that was pointing to hog waste killing fish in the river as "pseudo-science" (p. 27).

The hog industry's legitimacy claims-making extended beyond regular news columns and into the Have Your Say column. This is the section of the newspaper typically associated with contributions from individual members of the public, voicing opinions about current news events. A letter, by Andrew Dicksen of the Manitoba Pork Council, featured as the "Letter of the Day" in the Have Your Say column (\#104, 15 September 2011). The letter in the Have Your Say column mirrored the sentiment in Dicksen's interview reported a week earlier (\#102, 9 September 2011). Below is Dicksen's "Letter of the Day":

"Hog manure has small amounts of plant nutrients, which are best applied to fields to grow the crops we need to feed people and animals. Contrary to the mythology in government news releases, hog manure does not run off fields into Lake Winnipeg. It is incorporated into the soil and stays there for the next crop. And we are using the latest environmental technologies. We are still waiting for the government news release claiming Elvis is alive." (\#104)

The blaming hog farmers narrative frame is seen in this letter just as in the news articles. Extending the coverage of the blame hog farmers narrative frame to the Have Your Say column serves to further the hog industry's symbolic legitimacy claim. Placed in this column, Dicksen's letter gets interpreted, not as the claim of a leading industry spokesperson, but as an individual offering 'lay' knowledge of hog manure, in an attempt to correct what he refers to as the government's "mythology" methods of acquiring knowledge. Hays' (2000) analysis of the environmental opposition shows that, as part of their public relations campaigns, they often argue that pollution has natural causes (p. 120). A similar claim is made in Dicksen's Letter. In addition, industry leaders throughout the history of the environmental movement have pointed out the ways in which they are now reformed as 'green', and 
that existing regulations are sufficient, but that more regulation would be excessive (Hays, 2000: 218). This sentiment is also seen in the rhetoric used by Dicksen.

The extension of the narrative frames, constructed in the news articles, into the Have Your Say column does not go unnoticed by the readers. Two letters of critical response to Dicksen's letter were published in the Have Your Say column four days later (\#106, 19 September 2011):

"Now isn't this great news. Andrew Dicksen of the Manitoba Pork Council tells us that hog manure does not run off fields into Lake Winnipeg. Yet the council itself has told us many times that 1.5 per cent of the phosphorus is the hog producers' contribution to the waters of Lake Winnipeg. That figure, by the way, is manure. Also, it's against the law. Have all the scientists, including University of Manitoba soil expert Don Flaten, been wrong all these years about the amount of phosphorus exceeding crop requirements? Is the lake polluting itself? With the Free Press having given Dicksen Letter of the Day status for his hogwash, I have every confidence that you will be reporting, any day now, that Elvis is alive." (\#106)

"Andrew Dicksen should try reading the government news releases announcing the 2006 report by the Lake Winnipeg Stewardship Board or the 2008 report by the Clean Environment Commission. Not only do these reports affirm the obvious - that runoff from hog manure field application is a fact of life and a contributor to the biologically deadly nitrification of Lake Winnipeg - but the Manitoba Pork Council itself has long acknowledged this fact while using junk science to lowball the extent. I'm waiting for another news release: 'hog industry launches attack campaign to defeat tough-on-pollution NDP government'”, (\#106)

These letters reject Dicksen's 'lay' science. They also reject what they seem to view as a violation of the commonly understood function of the Have Your Say column. The first letter objects to the Winnipeg Free Press giving Dicksen's letter the Letter of the Day status, and the second letter identifies Dicksen's letter as part of the hog industry's "attack campaign". These responses show an acute reflexivity of readers around the use of narrative frames in the news, and also around the perceived misuse of the Have Your Say column to extend the legitimacy claims, or "attack campaigns" of powerful actors. 


\subsubsection{Economic consequences and the blaming hog farmers narrative frame}

The blaming hog farmers narrative frame included a repeated mention of economic consequences to the regulations. This included claims that the regulations would cause "harm" to a "valuable" or "billion dollar industry", cause the industry to "run out of pigs" and would cause "harm" to "communities", "families", "family businesses", "farms" and "farmers", as well as a "loss of jobs". The language used in this discourse is rhetorical, and serves more to further the hog industry's legitimacy claim rather than to accurately provide information about real economic consequences that may result from the new regulations.

The rhetorical economic consequence discourse used to oppose the environmental regulations is shown in the following quote from Karl Kynoch, Chairman of the Manitoba Pork Council:

"This act will not "save Lake Winnipeg" - far from it. But it will slowly kill the billion-dollar pork industry in this province and put at serious risk more than 3,000 direct unionized jobs in Winnipeg, Brandon and Neepawa involved in processing pork, as well as another 8,000 jobs spread throughout the province. Unfortunately, simply naming an act "Save Lake Winnipeg" does not mean it actually does. Banning barns will not help the lake one iota since it is already illegal to allow any manure to run off into waterways. " (\#68)

Here, Kynoch asserts that the Act will "slowly kill" the "billion dollar" industry, and threatens a loss of jobs. Another example is from an interview with Andrew Dicksen, also of the Manitoba Pork Council:

'“It is a politics of fear', Dicksen said. 'They have created a bogeyman and the implication is if we run short of pigs, you won't have a plant in Brandon and all those unionized jobs in Brandon, ditto in Neepawa.' The province has a system that provides quality food on a competitive basis to export markets in Japan and the U.S., he said.” (\#102)

Dicksen refers to a "loss of unionized jobs" as well as the possibility that the regulations will cause the farmers to "run short of pigs". Dicksen emphasises the value of the hog industry, which he reports is to "provide quality food ... to export markets". The mention of "quality food" is a symbolic legitimacy effort to appeal to a public by gaining their respect through a commonly shared good - "quality food". Dicksen also uses emotional tropes to describe the government's actions, 
including the use of the phrase "politics of fear" and "bogeyman". These tropes extend the blaming hog farmers narrative frame by portraying the government as an antagonist, and the hog industry as the victim.

The hog industry assert that the regulations will have consequences to "farms", "communities", "family businesses" and "families". For example, Graham Starmer, Manitoba Chambers of Commerce, is cited here:

"Starmer said many producers have invested millions in their operations and those family businesses need to have greater certainty they will be able to exist for future generations." (\#102)

A possible contradiction appears in Starmer's reference to "family businesses" being capable of "investing millions". Starmer may actually be referring, not to the small family-run farms that are conjured up in the image of a "family business", but of the much larger-scale industrial hog production plants typical of hog farms in Manitoba since the 1990s. This contradiction will be discussed further in the section 3.6.

What is important to note about the economic consequences outlined in the above examples is that they do not explain exactly how the regulations will cause a loss of jobs. The actual consequences are not clear. However, the rhetorical economic consequence discourse in the blaming hog farmers narrative frame has considerable emotional, cultural and social significance. The rhetoric is used, not to provide information to a public on real economic consequences of government legislation, but to persuade a public into believing that the Act is detrimental to them, their communities, their families, their businesses and their jobs.

In fact, the Save Lake Winnipeg Act has no direct economic consequences. To recap, the Save Lake Winnipeg Act (a) banned new hog farms that do not comply with advanced practices, (b) turned the existing regulation against winter spreading into a provincial law, (c) extended the zone where it is prohibited to build new hog farms, and (d) provided tax credits to farms that already comply with regulations. For an industry that already had regulations set for (a) and (b) (although these had not been adequately enforced, as is explained later in section 3.6), there is no economic consequence for farmers already complying with the regulations. There 
is minimal economic consequence for (c), because if a hog business wanted to expand, they would simply need to do so within zones designated for agricultural production. Finally, (d) is an economic incentive rather than a consequence, and is also the least discussed aspect of the Act in the news articles. The fact that (d) is not discussed suggests that it is the hog industry's interests that are dominating the discourse around the Save Lake Winnipeg Act.

The rhetorical economic consequence discourse seen in the blaming hog farmers narrative frame does not give the public the information required to engage in a real discussion of economic consequences versus environmental benefits. Thus, the blaming hog farmers narrative frame serves the hog industry more than it serves a public needing transparent access to information about public policy decisions.

\subsubsection{The Save Lake Winnipeg rhetorical motif in the blaming hog farmers narrative frame}

Throughout the blaming hog farmers narrative frame, the hog industry voiced unwavering support for saving Lake Winnipeg despite not agreeing with the regulations, feeling "singled out" and "blamed", being skeptical of the science and expressing a fear of the economic consequences. The Save Lake Winnipeg rhetorical motif is used throughout the articles, both by journalists and by the hog industry leaders, but the best example of its use is in the full-page advertisement sponsored by the Manitoba Pork Industry and other industry bodies, printed in the Winnipeg Free Press in September 2011 (\#91, see Appendix II for the full advertisement). The Manitoba Pork Council's advertisement is an attempt by the Council to make a legitimacy claim and gain public support for opposing the Save Lake Winnipeg Act. The advertisement's statement - "we ask Manitobans to support us" is a direct indication of this.

The Save Lake Winnipeg rhetorical motif is repeated throughout the hog industry's discourse, because it is a central symbolic asset for their legitimacy claim. The advertisement draws heavily on the Save Lake Winnipeg rhetorical motif right from its title, "Saving Lake Winnipeg: A letter of concern for the business community". The graphic featured in the background of the advertisement is a photo of Lake 
Winnipeg - a symbolic indication that the letter is meant to align with the Save Lake Winnipeg cause. The message contained in the advertisement is that the Save Lake Winnipeg Act will not do what it proposes to do and protect the lake; it will not "help solve Lake Winnipeg's problems". It draws on the government-as-foolish trope by referring to part of the Act as a "simplistic ban". There is reference to the "good" science rhetoric to support this claim, as the data quoted in the advertisement comes not from the recent Leavitt et al. (2011) report that informed the Save Lake Winnipeg Act, but the Lake Winnipeg Stewardship Board (2006) report attributing a lesser percentage of the phosphorus to the hog industry. The advertisement also claims that the Act was introduced "without consultation", despite the fact that the government offered a public hearing before the Act was passed and no representative from the hog industry showed up on the day of the hearing. The advertisement offers alternative solutions to protect the lake, such as the vaguely worded solution of "better water management".

The advertisement received a critical response from a reader, which was published in the Have Your Say column:

"Shame on the Free Press for accepting money from hog processing businesses to print (several times) a full-page advertisement under the false headline "Save Lake Winnipeg." The ad essentially claims that because most phosphorus comes from other sources, the provincial government should license more hog barns to dump more phosphorus into Lake Winnipeg. It doesn't speak well of the business community that the Manitoba Chamber of Commerce and the Manitoba Employers Council (which includes the City of Winnipeg among its members) should support an increase in the chemical behind the destructive algae bloom. Let the business community urge the provincial government to uncover and oppose the other sources of phosphorus pollution, including negotiating with state governments in the U.S. I wonder how Winnipeggers would react if a Free Press client took out an ad entitled, "Saving the Jets" and the proceeded to urge Manitobans to sabotage the hockey team." (\#108)

The letter is interesting for two reasons. First, the letter exposes the Manitoba Pork Industry for supporting the Lake Winnipeg cause in a "false" way. The writer compares the industry's use of the cause to support their own aims to someone claiming to support the Jets (Winnipeg's National Hockey League team), only to later "sabotage" the team. The writer of this letter not only recognises the use of 
the Save Lake Winnipeg rhetorical motif, but he rejects how it is being used in a misleading way by the Manitoba Pork Industry to oppose environmental regulation.

The second reason why the letter is interesting is because it appears to reject the Manitoba Pork Council using an advertisement to give their message. The letter begins with, "shame on the Winnipeg Free Press for accepting money from the hog processing businesses". This expresses opposition to the use of the advertising space for a political rather than commercial message. This opposition is similar to the critical responses to Andrew Dicksen's legitimacy claims-making in the Have Your Say column (\#104). Both responses express a desire to uphold commonly held assumptions about the boundaries of public political discussion in a newspaper, and the importance of distinguishing commercial interest from political discourse.

\subsection{Adding context to the blaming hog farmers narrative frame}

When news media report issues as one-off events without asking 'why' a problem occurs, environmental issues become decontextualised from their complex causes, and the public are unable to understand how an issue affects them directly (Boykoff, 2009). Information about the issues then becomes re-contextualised into constructed narrative frames in news media coverage (Maier, 2011). The Lake Winnipeg issue became decontextualised in the news coverage, and then recontextualised into the blaming hog farmers narrative frame. In order to understand how the story could be framed differently to improve transparency, it is useful to ask what has been left out of the narrative frame. This section adds context to the Lake Winnipeg issue by discussing some of all the political, social and cultural factors involved in large-scale hog production in Manitoba

\subsubsection{Farming in Manitoba - a changing landscape}

The term "hog farmer" is almost universally used in the news articles to describe the hog-production industry. The word "farmer" is rich in cultural significance for Manitobans. For the historically rural province, the word triggers a sense of nostalgia, sentimentality, loss of an old way of life, and sympathy for the challenges rural communities have faced, particularly in the last 40 years. News reports claiming that farmers are being "blamed" for environmental problems are likely to 
be strongly received by Manitobans, who associate farming with hardship. However, the use of the term "farmer" in the articles referring to hog industry producers is problematic. Most pork producers in Manitoba (in 2011) are not farmers in the sense that Manitobans know farmers, but leaders and employees of multinational industrial businesses running large-scale factory farms, some slaughtering around 90,000 pigs per week in sterilised barns. The problem is that they are still using the same term as they were one hundred years ago to describe what has become a vastly different occupation and industry.

The Manitoba farming industry has undergone significant change since the 1970s. Agriculture in this region has moved from small-scale wheat farming to industrial mass-production of livestock. In his article, "Intensive hog farming in Manitoba: Transnational treadmills and local conflicts", Joel Novek (2003) describes the history of farming in Manitoba. Farming was largely wheat-based until the agricultural economy went into decline between the 1970s and the 1990s (Novek, 2003: 5). The decline was mainly due to depressed prices in world grain markets, and higher grain shipping costs which led to railway deregulation (Novek, 2003: 5). The proportion of Manitobans who lived on, or were employed by, farms went from 13 per cent to 7 per cent between 1971 and 1996 (Novek, 2003: 5). As a result of the decline in wheat-based agriculture, "pork producers from Northern Europe to North Carolina facing environmental and regulatory constraints were welcomed to Manitoba's greener pastures" (Novek, 2003: 6). The scale of hog farms over this time has changed significantly. From 1981 to 2000 the number of pig farms in Manitoba went from 5,098 to 1,430, with the average number of pigs per farm rising from 172 to 1,354 in those same years (see table on page 69). 
Number of pig farms and average number of pigs per farm, Manitoba and Canada, 1981-2000*

\begin{tabular}{|c|c|c|c|}
\hline Year & $\begin{array}{c}\text { Number of pig } \\
\text { farms, Manitoba }\end{array}$ & $\begin{array}{c}\text { Average number of pigs per } \\
\text { farm, Manitoba }\end{array}$ & $\begin{array}{c}\text { Average number } \\
\text { of pigs per farm, } \\
\text { Canada }\end{array}$ \\
\hline $\mathbf{1 9 8 1}$ & 5098 & 172 & 177 \\
\hline $\mathbf{1 9 8 6}$ & 3563 & 301 & 268 \\
\hline $\mathbf{1 9 9 1}$ & 2969 & 434 & 345 \\
\hline $\mathbf{1 9 9 6}$ & 2064 & 861 & 523 \\
\hline $\mathbf{2 0 0 0}$ & 1430 & 1354 & 884 \\
\hline
\end{tabular}

* Statistics Canada, 2001; in Novek, 2003: 7

By 2000, hogs were the leading source of agricultural revenue in Manitoba (Novek, 2003: 7). Approximately half of Manitoba's hog production now comes from the 99 largest hog barns, which hold around 10,000 pigs each (Novek, 2003: 8). One of these, located in Brandon, Manitoba, is Canada's largest packing plant with the capacity to slaughter 90,000 pigs per week. This plant is owned by Maple Leaf Foods - part of McCain's multinational "agrifood empire” (Novek, 2003: 7). Three of Canada's ten largest pig production companies are now based in Manitoba (Novek, 2003: 9).

Due to the switch to larger scale pig production in Manitoba, it is rare for farmers to own small-scale autonomous farms, as is suggested by the blaming hog farmer rhetoric that refers to Manitoba farms as "family businesses". Manitoban farms are now typically part of a system known as "vertical co-ordination" (Novek, 2003: 9). Within this system, the farmer supplies the labour and the land on which liquid waste is spread. However, farmers are now dependent on overarching management companies to supply them with what they need to operate their plants, such as the pigs, feed, antibiotics, veterinary services and "the climate-controlled structures in which the hogs spend their short lives" (Novek, 2003: 9). The farmers are also dependent on the management companies to sell their products to overseas markets.

Changes to the agricultural industry in Manitoba have caused community breakdown within rural parts of the province, as a result of what Giddens (1990) and Granovetter (1985) call a process of disembedding. This is where economic activity becomes separated from the social bonds of local communities (in Novek, 
2003: 4). The plants are owned and managed non-locally, and make their supply purchases in bulk from low-price sources outside the communities they enter and operate in. This results in a loss of local economic control (CCPAM, 1999: 3).

Rural Manitobans were offered no consultation or choice in the changes that occurred in their communities as a result of the introduction of large-scale hog production. They were left out of the governmental decision-making processes that allowed large-scale hog production to enter their towns. In 1999, the Manitoba Government approved the construction of the Maple Leaf Foods pig processing plant in Brandon, Manitoba without a citizens' hearing normally required for developments of this scale. A citizen-organised hearing was held anyway, after the plant was approved to discuss the community's growing concerns about the new plant. The Canadian Centre for Policy Alternatives - Manitoba (CCPAM) produced a report documenting the discussions held during the citizen-organised hearing in October 1999. The hearing included discussions of the well-known environmental hazards of large-scale meat processing, and the detrimental socioeconomic impacts already seen when similar meat-processing industries had entered communities across North America. The North American cases showed increased incidents of unemployment and homelessness, as well as increased incidents of murder, assault, robbery, driving while intoxicated, domestic violence, child abuse, and drug abuse (CCPAM, 1999: 13). Citizens expressed concern that employee conditions in pig processing plants are poor - wages are low, the work is difficult and dangerous, and this leads to a high turnover of jobs, so employees tend to be young and highly mobile migrant workers (CCPAM, 1999: 2). Employees frequently suffer from poor health as a result of working in the plants. For example, the CCPAM (1999) report claimed that 25 to 30 per cent of workers inside pig processing plants develop chronic respiratory disease (such as asthma and chronic bronchitis) as a result of organic dust syndrome (pp. 7-8).

Adding context to the blaming hog farmers narrative frame, within the changing landscape of Manitoban agricultural production and rural life, offers interesting insights. The news coverage of the Save Lake Winnipeg Act is dominated by the legitimacy claims-making of the very industrial leaders involved in economic 
processes that have caused detrimental environmental and socio-economic effects across the province. The blaming hog farmers narrative frame is constructed in a way that omits the causal linkages between environmental destruction and socioeconomic community breakdown with a global system of industrial production that perpetuates these problems.

\subsubsection{Hog farmers "surprised" by the science?: known environmental problems with hog production}

“Farmers were surprised by the report's conclusions..." (\#51)

"The portioning of blame was an unpleasant surprise for farmers in this province..." (\#93)

News articles reported that the hog farmers were "surprised" by findings that the hog industry may be contributing 50 per cent of the excess phosphorus in Lake

Winnipeg. However, the effects of hog farming on the environment, particularly on the water quality of nearby rivers and lakes, are well-known. There is general agreement among environmental scientists that factory hog farming is one of the most unsustainable practices in agriculture (Stocking and Holstein, 2009). The CCPAM (1999) report predicted that the introduction of large-scale hog plants in Manitoba would have detrimental effects on the Lake Winnipeg Watershed. Based on research conducted on similar North American large-scale hog processing plants, the scientists who presented at the citizen's hearing in Brandon in 1999 expected that the new Maple Leaf Plant "could exacerbate existing algae bloom problems" (p. 22). The CCPAM report also stated that, "millions of extra dollars are expected to be needed for remedial work to deal with ammonia and phosphates in the discharges from the Maple Leaf plant at Brandon" (1999: 17). Similarly, at the time of writing his report on the Manitoba hog industry in 2003, Novek warned that "hog wastes may be responsible for nitrate leaching and phosphorus runoff in water, as well as the release of harmful pathogens and offensive odours" (2003: 4).

The environmental problems with hog production are not only known by scientists, but also by members of the public. In a Canadian national poll in 1998, Canadians rated hog barns as the most environmentally hazardous form of agriculture, and 
water quality as the biggest concern (Novek, 2003: 18). Environmental problems with hog production include the cruel treatment of pigs in the plants and the considerable amount of water required for production. These problems are beyond the scope of this research, however, which is limited to the impact of manure waste on toxic algae growth in Lake Winnipeg.

In the blaming hog farmers narrative frame, two scientific reports were compared. Their differing conclusions were highlighted rather than their areas of agreement, to sustain a trope of uncertainty around the lake science. What was left out of the news coverage was that both scientific reports concluded that hog production was a significant cause of the algae pollution in Lake Winnipeg. Moreover, the coverage left out that reports align with a general agreement among environmental scientists that large-scale hog production is environmentally destructive to surrounding water ecosystems.

\subsubsection{Inadequate regulation of the Manitoban hog industry}

There is already a total ban on expansion on the eastern side of the province. Livestock operations must already file manure-management plans with the province. It's highly doubtful anyone proposing antiquated or harmful practices would be allowed to proceed.

- Laura Rance, editor of the Manitoba Co-operator (\#62)

The news coverage about the Save Lake Winnipeg Act, like the above quote, repeated the idea that existing regulations were enough to control the hog industry from harming Lake Winnipeg, and insisting that new, tougher legislation was not required. However, within Manitoba there is a history of inadequacy of regulation compliance and enforcement with the existing hog industry regulations. The story in the news coverage overlooks how difficult it has been for governments to regulate the powerful multinational industries that control hog production in Manitoba.

Joel Novek's article (2003) provides a history of environmental regulation of hog farming in Manitoba. Odour problems were the first environmental problems relating to hog production in the early 1970s, as pig manure contains high amounts of nitrogen, ammonia and phosphorus - nutrients that produce bad odours. The 
first legal complaints about the odours came from neighbours of the plants. In 1994, the government of Manitoba responded by introducing the Farm Practices Protection Act. The Act was introduced to protect hog industry leaders from lawsuits (Novek, 2003: 10-11). At the time, news coverage of the Farm Practices Protection Act portrayed environmental critics of the Act as "anti-agricultural zealots who would deprive legitimate farmers of their right to earn a living" (Novek, 2003: 12).

Despite initial resistance to environmental regulation, in 1989 the Manitoba Clean Environment Commission placed hog processing businesses under environmental regulations, based on the number of animal units on their farms (Novek, 2003: 12). In 1994, hog businesses with 400 animal units or more were required under a new regulation to submit a manure management plan and undergo an inspection of their manure storage facilities (Novek, 2003: 13). Then in 2000, a regulation was added that all new hog barn proposals must undergo a "technical review" (Novek, 2003: $13)$.

The regulations in place before the Save Lake Winnipeg Act were not successful due to the lack of enforcement. In 2000, there were only 16 inspectors to inspect all the hog farms in Manitoba, in addition to the 12,000 beef livestock producers in Manitoba (Novek, 2003: 13). Furthermore, Novek (2003) reported that there has been "widespread anecdotal evidence of non-compliance" (p. 13). Only 50 enforcement or compliance orders were carried out under the Manure and Mortalities Regulation, and most of these orders resulted in warnings rather than fines or other penalties (Novek, 2003: 14). With regard to the new hog barns having to undergo a technical review, out of 2,000 new hog barns introduced, not a single review had recommended rejection of a proposal (Novek, 2003: 14). Novek (2003) suggests that regulation, as a method of protecting the environment in industrial society, is intrinsically inadequate. It has proven to be more of a "form of legitimation" for the hog farmers, who are able to say that they are compliant with environmental regulation once they have undergone a review (Novek, 2003: 22). 
Another challenge for the Manitoba Government is that the Lake Winnipeg Watershed extends beyond Manitoba and Canada. The Manitoba Government can attempt to regulate what happens within the province, but Lake Winnipeg is affected by activities throughout the entire Watershed, which crosses provincial and national boundaries. Solutions to Lake Winnipeg's environmental problems will need to include negotiation between multiple governments and as yet, no inter-governmental discussions have taken place around protecting Lake Winnipeg.

In the news coverage around the Save Lake Winnipeg Act, Greg Selinger, the Premier of Manitoba, was quoted in an article stating:

"We want the industry to be able to function... but we want safe environmental practices" (\#55)

The quote reflects the dual and conflicting role of governments, described in Chapter Two. The government is often reluctant to impose environmental standards because of its dual and contradictory role as both promoter of economic growth, and protector of the environment (Novek, 2003: 5). There is also a power imbalance between the local governments in rural Manitoban communities, and between the Manitoban provincial government and the hog industry leaders. Most Manitoban municipalities are poorly equipped to go up against these industry leaders. Few municipalities partook in development planning at all before 1982 (Novek, 2003: 14). Most of them lack legal authority to control the hog industry. The news coverage of the Save Lake Winnipeg Act omits the power relationships involved between governments and industries, and the difficulties governments have in introducing environmental regulations.

\subsection{Summary}

This chapter has given a critical discourse analysis of the news coverage of the Save Lake Winnipeg Act in the Winnipeg Free Press. This analysis includes a contextual analysis of the political, cultural and historical setting in which the news discourse takes place, to understand the significance of the coverage for its Manitoban readers. The news coverage studied both decontextualises events and information from their original setting, and re-contextualises them to serve legitimacy claims made by the City of Winnipeg and the hog industry. The 
coverage provides inadequate and misleading information to the public about political decisions (such as the government's unexplained \$26 million contribution to the hog industry), scientific knowledge, and the economic consequences of environmental regulation. Transparency of environmental discourse and policy in the public sphere is, thus, impeded when context is removed from news stories.

Two narrative frames are found in the coverage, each supporting legitimacy claimsmaking efforts of the city of Winnipeg and the hog industry. The nitrogen debate narrative frame represents a legitimacy claim made by the city to justify their insistence on not filtering sewage waste for nitrogen as well as phosphorus. Journalists frame the story in a way that supports the city's claim by portraying the City as the protagonist and the Manitoba Government as the antagonist. The second narrative frame, blaming hog farmers, served the hog industry in gaining legitimacy for opposing the new regulations. Language within the blaming hog farmers narrative frame was richly emotional and sympathetic to farmers (protagonists), portraying the Manitoba Government as an irrational, foolish and fear-inducing antagonist. The rhetorical themes and patterns of meaning used to support the blaming hog farmers narrative frame are not unique to this case - similar patterns of narratives over time, described by Stocking and Holstein (2009) and Hays (2000), closely compare to those used in this narrative. This analysis describes the cultural and historical context within which the hog farmer conflict may have been received by Manitoban readers of the newspaper. Manitoban farmers and rural communities have, in the last 40 years, undergone considerable socio-economic challenges as a result of the introduction of large-scale hog farming to the province.

The Save Lake Winnipeg rhetorical motif is used throughout the coverage by legitimacy claims-makers. The motif draws on a genuine concern among Manitobans for the health of Lake Winnipeg, based on the local cultural significance of lake and cottage life, increased awareness of algae and other environmental problems with the lake, and heightened media attention to lake issues due to the 2011 provincial election. The Save Lake Winnipeg rhetorical motif was used to attribute moral significance to the legitimacy claims of the hog industry and the city of Winnipeg, because it is a strong symbolic asset in this cultural setting. 
Hog industry leaders extended their legitimacy claims into both the Have Your Say and advertising columns of the paper. The newspaper published letters by industry leaders in the Have Your Say column and assigned them "Letter of the Day" status. The newspaper also published an advertisement sponsored by the hog industry urging the public to support the industry in opposing the Save Lake Winnipeg Act. The industry took advantage of commonly held assumptions about the functions of these separate columns in the newspaper. The Have Your Say column is understood to be a space for public opinion. Public opinion is assumed to have credibility because 'regular' members of the public are trusted not have hidden motives. The Have Your Say column, as a public opinion space, was used as a legitimacy boundary by the industry leaders writing letters to the Have Your Say column, and they attempted to place their claims within this boundary. However, some readers had critical responses to these attempts, accusing them of being deceptive. The use of the advertising space by the industry to influence public opinion also received a critical response. This may be because it is assumed that the advertising space is reserved exclusively for selling goods and not for influencing public opinion on political issues.

Science was the central focus of the conflict in both narrative frames. News coverage of the Save Lake Winnipeg Act created a frame of conflict around the science, conveying that the science was uncertain. This occurred despite the recent Lake Winnipeg findings generally aligning with the wider scientific community on the impact of large-scale hog production on the environment. The treatment of the science in the narrative frames aided the legitimacy claims of the City of Winnipeg and hog industry by sustaining a trope of uncertainty around the science. Science was also used as a central symbolic asset to attribute moral significance to the City's claim during the nitrogen debate. The treatment of the science, as the central point of conflict in the coverage, served to maintain the preferred invisibility of the environmental opposition. This was achieved by deflecting negative attention away from the 'guilty' industry. 
Both narrative frames conveyed that the Save Lake Winnipeg Act held economic consequences for the province. In particular, the blaming hog farmers narrative frame featured industry leaders warning farmers about the cost of the regulations on families, communities and farms. What is missing from this simplistic cost/benefit analysis is an informed public discussion of the actual economic, social and environmental consequences of the large-scale hog industry in Manitoba. In fact, the Save Lake Winnipeg Act has no direct economic consequences on industries or communities. Rather, the presence of the large-scale hog industry in Manitoba since the 1990s has had an array of economic, social and environmental consequences for Manitobans who have had no consultation or control over these changes, which have had detrimental effects on their communities. Farming in Manitoba now looks vastly different than it did 40 years ago, as farmers now rely on a chain of multinational suppliers and are rarely the quaint family businesses conjured up by the rhetorical language used in the news coverage. A public discussion is desperately needed in Manitoba between governments, industries and the public about the impacts of industries and governmental decisions on Manitoban communities and the environment. However, this discussion requires transparent news coverage of economic and environmental policy decisions.

Both narrative frames portrayed the Manitoba Government as irrational antagonists operating outside of the legitimacy boundaries of 'good reasoning'. The negative portrayal of the government throughout the coverage overlooks the difficulties governments face in fulfilling their dual conflicting role to promote economic development and protect the environment. Despite the news coverage portraying that the Manitoba Government is going too far with the regulations, based on the difficulties of regulating this industry in the past, the government has in fact not gone far enough in executing its role as environmental protector in this case. 


\section{4}

\section{Discussion}

In post-environmental discourse, environmentalism becomes, ironically, topical. It becomes talked about by everyone, and yet discussed by no one. In my analysis, Lake Winnipeg was a key political issue in the news discourse. This was shown by the repeated and shared use of the Save Lake Winnipeg rhetorical motif by journalists, government, the City of Winnipeg and the hog industry. However, this thesis concludes that an actual debate about Lake Winnipeg's environmental problems, and their complex causes, was absent from the discourse. The Save Lake Winnipeg rhetorical motif reduced the issue to a symbolic asset that was used repeatedly by the City and the hog industry as part of their rhetorical claims for opposing environmental regulations. An open debate about the issue's complex political context was, thus, excluded from the discourse.

The public-sphere-turned-marketplace is a dysfunctional discursive arena lacking in democratic transparency. The influence of the media political economy on news discourse causes this dysfunction through journalistic micro-processes, as well as macro-power relationships between media institutions and the political economic domain they operate within. These dynamics allow powerful actors to maintain a stronghold over the news discourse. Consequently, news coverage of environmental issues is framed to support legitimacy claims-making. Legitimacy claims-making is a process through which actors in the public sphere 'earn' the legitimacy to speak on behalf of the environment. Through the use of the Save Lake Winnipeg rhetorical motif, the lake was decontextualised from its original moral significance as an environmental cause, and re-contextualised into the narrative frames to aid the legitimacy claims-makers.

The environment cannot speak for itself, so someone must speak for it in the public sphere. In order to address the complexity of political and economic causes to 
environmental problems, dominant assumptions about unlimited economic growth must be challenged by the presence of a counter-discourse in the debate. Although the need to save Lake Winnipeg was frequently mentioned in the articles, the discussion lacked any real political debate about the issue because a counterdiscourse was absent. Eder (1996) describes environmental discourse up to the 1980s as a discourse that was initiated by environmentalists, or protest actors. These protest actors challenged the dominant paradigm and offered a new set of values. Environmentalists insisted that unlimited economic growth was not possible on a finite planet, and that humans needed to adjust their beliefs and activities in order to restore ecological balance. However, environmentalism as a counter-discourse was not present in this instance. The discourse on the environment that I observed was dominated by the two narrative frames serving the legitimacy claims of the city and hog industry.

A post-environmental discourse is further evidenced by the treatment, by Winnipeg Free Press journalists, of the Lake Winnipeg cause as being in a 'maintenance' phase of its issue life-cycle. The 'maintenance' phase describes the phase of an issue in the news after it has achieved acceptance, and has been initiated toward resolving it. I suggest that an issue life-cycle is a type of meta-framing of the issue over its time in the news. As such, it is subject to being manipulated by powerful actors in the legitimacy claims-making process. The news articles I analysed frame the government/industry negotiations around the Save Lake Winnipeg Act as technical and administrative, implying that the problem is being 'managed' by these actors. The issue life-cycle furthers the legitimacy claims-making of the opposition by conveying the message that an issue is being resolved and is, therefore, on its way 'out' of public discussion.

It is important to provide transparency of scientific knowledge in environmental discourse. It is not only important to inform the public of new scientific findings, but also to assess new findings in relation to the existing pool of knowledge on a subject. However, in the news coverage of the Save Lake Winnipeg Act, new science was either credited or discredited to benefit the City of Winnipeg and hog industry's claims. The coverage, therefore, did not accurately convey the validity 
of the science. The narrative frame included labeling science as 'good' or 'bad', attacking individual scientists personally, and pitting two slightly varied findings against each other. These two scientific findings were portrayed as conflicting, despite the fact that they aligned with existing research on Lake Winnipeg. In addition, they also aligned with the wider body of research on the environmental hazards of hog production, as was outlined in Chapter Three. In a public-sphereturned-marketplace, science is used as a symbolic asset so that legitimacy claimsmakers can place themselves within a legitimacy boundary of 'good scientific reasoning'. This treatment of the science matches a wider pattern in environmental news discourse, where science is doubted by industries opposing governmental regulations. While it is important to ensure that the science used to inform policy is valid, it is equally important for news media discourse to provide fair treatment of science that does not favour powerful actors.

In the absence of a counter-discourse throughout the news coverage of the Save Lake Winnipeg Act, scientists ended up taking on the role of the 'blamer' in the narrative frames. Environmental discourse often becomes a conflict of accountability over who is responsible for environmental problems. However, without a protest actor, the only voices offering evidence for accountability are the scientists. Science that points to the source of environmental problems gets treated as the counter-discourse, for lack of another counter voice. In surn, the voice of the scientist is then discredited via a trope of scientific uncertainty maintained by the narrative frames. Environmental discourse in the public sphere needs to enable the presence of other voices besides scientists to make claims of accountability for environmental problems.

The city and hog industry integrated the Save Lake Winnipeg rhetorical motif with their oppositional claims, in an attempt to render their anti-environmental stance invisible. In spite of this, the hog industry's anti-environmental use of the motif was detected by some writers to the Have Your Say column, and criticised for being deceptive. This shows that some members of the public are reflexive about how, and for whom, news discourse is framed. 
An interesting tension was observed in my analysis regarding the function of newspaper column categories. Based on letters in the Have Your Say column, I observed that newspaper column categories are assumed by some readers to equate with separate types of discourse in the public sphere such as news, public opinion and advertising. However, in a public-sphere-turned-marketplace, the boundaries between these public discourse categories are blurred. For example, the Have Your Say column was expected to be a space reserved for public opinion. Advertisements were expected to be the marketplace - separate from the space where news is produced. However, the hog industry's legitimacy claims-making rhetoric extended to all three spaces - the Have Your Say column, news articles and the advertising column. Letter writers in the Have Your Say column responded to this critically - the presence of the hog industry's rhetoric in all three spaces was viewed as deceptive. Further research on environmental news coverage could examine the assumed functions of newspaper column categories in the public sphere, and how distinct public discourse categories - news, public opinion and advertising - have become more ambiguous in a public-sphere-turned-marketplace.

The global environmental crisis is an institutional crisis, inherently connected to a global economic system of economic growth, development and trade. Therefore, resolving the environmental crisis is dependent on the public's ability to discuss the environmental/economic tension publicly and openly. The simplistic environmental/economic cost/benefit analysis found in the news coverage to assess the Save Lake Winnipeg Act was rhetorical and misleading rather than factual. While the coverage focused on 'detrimental' impacts of environmental regulation on the local economy, it omitted a discussion around the detrimental impacts of global economic growth and trade on local economies, communities and the environment. It fell short of addressing the larger economic/environmental paradigmatic tension between the value of finding ecological balance and the value of the pursuit of economic growth.

Governments have a conflicting role to simultaneously promote economic growth while protecting the environment. This conflicting role has impinged on the Manitoba Government's ability to regulate cities and industries for the protection of 
Lake Winnipeg in the past. Given the difficulty of governments to enforce regulations on multinational corporate industries, there is no guarantee that the Save Lake Winnipeg Act will provide sufficient protection for Lake Winnipeg in the future.

The increasing toxic algae outbreaks in Lake Winnipeg represent one environmental problem. However, there is no such thing as an isolated environmental problem Lake Winnipeg belongs to a series of lakes in Canada and the world that are all facing ecological deterioration. This is, in part, due to large-scale industrialised agriculture and the global economic system that drives it. The public sphere needs a news media discourse that provides transparent communication of environmental and political events as they unfold. This should include a fair presentation of environmental science by news media. It should also include a fair discussion of the environmental/economic paradigmatic tension, to allow a public to understand real economic costs to environmental solutions, as well as real environmental costs to industrial activities. Resolving the global environmental crisis will depend on transforming the public-sphere-turned-marketplace back to a public sphere that enables a public to debate the environmental/economic tension transparently and democratically. 


\section{Bibliography}

Agger, B. (1990). The Decline of Discourse: Reading, Writing and Resistance in Postmodern Capitalism. The Falmer Press: New York.

Agyeman, J. and B. Evans (2004). “'Just sustainability': the emerging discourse of environmental justice in Britain?” In The Geographical Journal (170: 2), June 2004, pp. 155-64.

Babe, R. (2005). "Newspaper discourses on environment." in J. Klaehn (Ed.), Filtering News: Chomsky's Propaganda Model. Black Rose Books: Montreal, Canada. Pp. 187-222.

Bax, S. (2011). Discourse and Genre: Analysing Language in Context. Palgrave Macmillan: Houndmills, England.

Beder, S. (1997). Global Spin: The Corporate Assault on Environmentalism. Scribe Publications Pty Ltd: Carlton North, Victoria, Australia.

Beck, U. (1992). The Risk Society: Towards a New Modernity. Sage: London.

Beck, U. (1995). Ecological Politics in an Age of Risk. Polity Press: Germany.

Beck, U. (1996). "Risk society and the provident state." In S. Lash, B. Szerszynski and B. Wynne (Eds.), Risk, Environment \& Modernity: Towards a New Ecology. Sage Publications Ltd.: London, England. Pp. 27-43.

Beck, U., A. Giddens and S. Lash (1994). Reflexive Modernization: Politics, Tradition and Aesthetics in the Modern Social Order. Stanford University Press: Stanford, California, United States. 
Bocking, S. (2004). Nature's Experts: Science, Politics, and the Environment. Rutgers University Press: New Brunswick, Canada.

Boykoff, M. T. (2008). "Fight semantic drift?: Mass media coverage of anthropogenic climate change." In Goodman, M. K, M. T. Boykoff and K. T. Evered (Eds.), Contentious Geographies: Environmental Knowledge, Meaning, Scale. Ashgate: Aldershot, Hampshire, England. Pp. 39-57.

Boykoff, M. T. (2008). "Lost in translation? United States television news coverage of anthropogenic climate change, 1995 - 2004.” In Climate Change (86), pp. $1-11$.

Boykoff, M. T. (2009). "We speak for the trees: media reporting on the environment." In The Annual Review of Environment and Resources (34), pp. 431-57.

Boykoff, M. T. (Ed.) (2010). The Politics of Climate Change: A Survey. Routledge: London.

Boykoff, M. T., M. K. Goodman and I. Curtis (2010). "Cultural politics of climate change: interactions in everyday spaces." In Boykoff, M. T. (Ed.), The Politics of Climate Change: A Survey. Routledge: London. Pp. 136-54.

Brossard, D., J. Shanahan and K. McComas (2004). “Are issue-cycles culturally constructed? A comparison of French and American coverage of global climate change.” In Mass Communication \& Society (7: 3), pp. 359-77.

Budds, J. (2008). "Whose scarcity? The Hydrosocial cycle and the changing waterscape of La Ligua River Basin, Chile.” In In Goodman, M. K, M. T. Boykoff and K. T. Evered (Eds.), Contentious Geographies: Environmental Knowledge, Meaning, Scale. Ashgate: Aldershot, Hampshire, England. Pp. 59-78. 
Burgess, J. (1989). "The production and consumption of environmental meanings in the mass media: a research agenda for the 1990s." In Transactions of the Institute of British Geographers (15: 2), pp. 139-61.

Butteriss, C., J. A. J. Wolfenden and A. P. Goodridge (2001). "Discourse analysis: a technique to assist conflict management in environmental policy development." In the Australian Journal of Environmental Management (8), March 2001, pp. 48-58.

Campbell, G. and M. Roberts (2010). "Permitting a new mine: insights from the community debate.” In Resources Policy (35), pp. 210-17.

Canadian Centre for Policy Alternatives - Manitoba (2000). "Large-Scale Hog Production and Processing: Concerns for Manitobans." Commissioners' Report on the Citizens' Hearing on Hog Production and the Environment, Brandon, Manitoba, October 1999. Published in May 2000.

Couldry, N. and T. Markham (2006). "Public connection through media consumption: between oversocialization and desocialization?" In Annals of the American Academy of Political and Social Science (608), November 2006, pp. 251-69.

Cox, R. (2006). Environmental Communication and the Public Sphere. SAGE Publications: Thousand Oaks.

Craig, G. (2010). "New Zealand Environmental Campaign Management and News Media Coverage.” In New Zealand Journal of Media Studies (12: 1), pp. 726.

Dijk, T. (1985). Discourse and communication: new approaches to the analysis of mass media discourse and communication. W. de Gruter: New York. 
Dudgeon, R. C. and F. Berkes (2003). "Local understandings of the land: traditional ecological knowledge and indigenous knowledge.” In H. Selin (Ed.), Nature Across Cultures: Views of Nature and the Environment in Non-Western Cultures. Kluwer Academic Publishers: Great Britain. Pp. 75-96.

Dunlap, R. E. (2008). “The New Environmental Paradigm Scale: From Marginality to Worldwide Use." In The Journal of Environmental Education (Fall 2008, 40: 1). Pp. 3-18.

Eder, K. (1996). "The institutionalisation of environmentalism: Ecological discourse and the second transformation of the public sphere." In S. Lash, B. Szerszynski and B. Wynne (Eds.), Risk, Environment \& Modernity: Towards a New Ecology. Sage Publications Ltd.: London, England. Pp. 203-23.

Environment Canada. (2012). Cleaning Up Lake Winnipeg. Retrieved from www.ec.gc.ca/doc/eau-water/winnipeg_e.html.

Environment Canada and Manitoba Water Stewardship. (2011). "State of Lake Winnipeg: 1999 to 2007 Highlights”. Government of Canada, June 2011.

Evans, M. S. (2000). “The large lake ecosystems of northern Canada.” In Aquatic Ecosystem Health \& Management (3: 1), pp. 65-79.

Forsyth, T. (2008). “The Contentious World of Jared Diamond's Collapse.” In Goodman, M. K, M. T. Boykoff and K. T. Evered (Eds.), Contentious Geographies: Environmental Knowledge, Meaning, Scale. Ashgate: Aldershot, Hampshire, England. Pp. 27-38.

Fraser, N. (1992). "Rethinking the public sphere: A contribution to the critique of actually existing democracy." In Habermas and the Public Sphere, C. Calhoun (Ed.). MIT Press. Pp. 109-42. 
Garnham, N. (1986). "The media and the public sphere." In P. Golding, G. Murdock and P. Schlesinger (Eds.), Communicating Politics: Mass Communications and the Political Process. Leicester University Press: United States. Pp. $37-$ 53.

Giannoulis, C., I. Botetzagias, and C. Skanavis (2010). 'Newspaper reporters' priorities and beliefs about environmental journalism: an application of QMethodology." In Science Communication (34: 4), pp. 425-66.

Goodman, M. K, M. T. Boykoff and K. T. Evered (Eds.) (2008). Contentious Geographies: Environmental Knowledge, Meaning, Scale. Ashgate: Aldershot, Hampshire, England.

Grove-White, R. (1996). "Environmental knowledge and public policy needs: on humanizing the research agenda." In S. Lash, B. Szerszynski and B. Wynne (Eds.), Risk, Environment \& Modernity: Towards a New Ecology. Sage Publications Ltd.: London, England. Pp. 269-86.

Guttman, N. (2007). "Bringing the mountain to the public: dilemmas and contradictions in the procedures of public deliberation initiatives that aim to get 'ordinary citizens' to deliberate policy issues." In Communication Theory (17), pp. 411-38.

Habermas, J. (1989). "Introduction: preliminary demarcation of a type of bourgeois public sphere." In J. Habermas, The Structural Transformation of the Public Sphere: An Inquiry into a Category of Bourgeois Society. Polity Press. Pp. 126.

Hajer, M. (1996). "Ecological modernization as cultural politics.” In S. Lash, B. Szerszynski and B. Wynne (Eds.), Risk, Environment \& Modernity: Towards a New Ecology. Sage Publications Ltd.: London, England. Pp. 246-68.

Hannigan, J. (2006). Environmental Sociology: Second Edition. Routledge: London. 
Hansen, A. (2011). "Communication, media and environment: Towards reconnecting research on the production, content and social implications of environmental communication.” In International Communication Gazette 2011 (73), pp. 7-25.

Harrison, N. E. and G. C. Bryner (eds.) (2004). Science and Politics in the International Environment. Rowman \& Littlefield Publishers, Inc.: Toronto.

Harper, K. (2005). “'Wild Capitalism' and 'Ecocolonialism': a tale of two rivers.” In American Anthropologist (107: 2), June 2005, pp. 221-33.

Hays, S. P. (2000). A History of Environmental Politics Since 1945. University of Pittsburgh Press: Pittsburgh.

Hendriks, C. M. (2005). "Participatory storylines and their influence on deliberative forums.” In Policy Sciences (38), pp. 1-20.

Howard-Williams, R. (2011). "Consumers, crazies and killer whales: The environment on New Zealand television.” In International Communication Gazette (73), pp. 27-43.

Hulme, M. (2008). "The conquering of climate: discourses of fear and their dissolution.” In The Geographical Journal (174: 1), March 2008, pp. 5-16.

Ingold, T. (2000). “Culture, nature, environment: steps to an ecology of life.” In T. Ingold, The Perception of the Environment: Essays in Livelihood, Dwelling and Skill. Routledge: London. Pp. 13-26.

International Lake Environment Committee (2012). International Lake Environment Committee. Retrieved from http://www.ilec.or.jp/database/nam/nam-08.html 
Jamison, A. (1996). "The shaping of the global environmental agenda: the role of non-governmental organisations." In S. Lash, B. Szerszynski and B. Wynne (Eds.), Risk, Environment \& Modernity: Towards a New Ecology. Sage Publications Ltd.: London, England. Pp. 224-45.

Johnson, L. (2009). “(Environmental) Rhetoric of Tempered Apocalypticism in An Inconvenient Truth". In Rhetoric Review (28: 1), pp. 29-46.

Kellow, A. (2007). Science and Public Policy: The Virtuous Corruption of Virtual Environmental Science. Edward Elgar: Cheltenham, UK.

Lake Winnipeg Foundation (2012). Lake Winnipeg Foundation. Retrieved from http://www.lakewinnipegfoundation.org/lake-winnipeg/challenges/

Lake Winnipeg Implementation Committee (2005). "Restoring the Health of Lake Winnipeg”. A Report transmitted to The Honourable Reg Alcock, President of the Treasury Board, Government of Canada, and The Honourable Steve Ashton, Minister of Water Stewardship, Province of Manitoba.

Lake Winnipeg Stewardship Board (2006). "Reducing nutrient loading to Lake Winnipeg and its Watershed." A Report to the Minister of Water Stewardship. December 2006. Retrieved from http://www.gov.mb.ca/waterstewardship/water_quality/ lake_winnipeg/lwsb2007-12_final_rpt.pdf

Lash, S., S. Bronislaw and B. Wynne (eds.) (1996). Risk, Environment and Modernity: Towards a New Ecology. Sage Publications Ltd.: London, England.

Linnros, H. D. and P. O. Hallin (2001). "The discursive nature of environmental conflicts: the case of the Öresund Link." In Area (33: 4), December 2001, pp. 391-403. 
Lockie, S. (2006). "Capturing the sustainability agenda: organic foods and media discourses on food scares, environment, genetic engineering, and health." In Agriculture and Human Values (23), pp. 313-23.

Luke, T. (1995). “On environmentality: Geo-power and eco-knowledge in the discourses of contemporary environmentalism". Cultural Critique (31), pp. $57-81$.

Luke, T. (1997). Ecocritique: Contesting the Politics of Nature, Economy, and Culture. University of Minnesota Press: Minneapolis, United States.

Luke, T. (1999). Capitalism, Democracy and Ecology: Departing from Marx. The Board of Trustees of the University of Illinois: United States of America.

Luke, T. (1999). “Environmentality as Green Governmentality.” In Darier, E. ed. Discourses of the Environment. Blackwell Publishers: Malden, MA. Pp. 12151.

McComas, K and J. Shanahan (1999). "Telling stories about global climate change: Measuring the impact of narratives on issue cycles." In Communication Research (26), pp. 30-57.

Maier, C. D. (2011). "Communicating business greening and greenwashing in global media: A multimodal discourse analysis of CNN's greenwashing video.” In International Communication Gazette (73). Pp. 165-77.

Macdonald, N. (2009). “Canada’s sickest lake.” Maclean's (20 August 2009). Taken from http://www2.macleans.ca/2009/08/20/canada\%E2\%80\%99s-sickestlake/.

Manitoba Bills. (2012). The Save Lake Winnipeg Act 2011. Retrieved from http://web2.gov.mb.ca/bills/39-5/b046e.php. 
Manitoba Hydro. (2012). Lake Winnipeg Current Status. Retrieved from http://www.hydro.mb.ca/corporate/water_regimes/lake_wpg_status.shtml.

Manitoba Water Stewardship. (2012). Water Quality Incidents. Retrieved from www.gov.mb.ca/waterstewardship/quality/incidents.html.

Manitoba Wildlands. (2012). Manitoba Wildlands. Retrieved from http://manitobawildlands.org.

Milton, K. (1996). Environmentalism and Cultural Theory: Exploring the role of anthropology in environmental discourse. Routledge: London.

Mühlhäusler, P. and A. Peace (2006). "Environmental discourses.” In Annual Review of Anthropology (35), pp. 457-79.

Mulkay, M. (1985). The word and the world: explorations in the form of sociological analysis. Allen \& Unwin: London.

Novek, J. (2003). "Intensive hog farming in Manitoba: Transnational treadmills and local conflicts." In The Canadian Review of Sociology and Anthropology, February 2003 (40:1), pp. 3-26.

Petersen, L. K. (2007). “Changing public discourse on the environment: Danish media coverage of the Rio and Johannesburg UN Summits." In Environmental Politics (16: 2), April 2007, pp. 206-30.

Powell, J. L. (2011). The Inquisition of Climate Science. Columbia University Press: New York.

Roberts, J. M. and N. Crossley (2004). "Introduction." In After Habermas: New Perspectives in the Public Sphere, J. M. Roberts and N. Crossley, Eds. Blackwell Publishing: The Sociological Review. Pp. 1-26. 
Sachsman, D. B., J. Simon and J. M. Valenti (2005). "Wrestling with objectivity and fairness: U.S. environmental reporters and the business community." In Applied Environmental Educaiton and Communication (4: 4), p. 363-73.

Simon, J. (2009). “Unnatural disaster: The crisis of environmental journalism.” In World Policy Journal (spring), pp. 87-94).

Stocking, S. H. And L. W. Holstein (2009). "Manufacturing doubt: journalists' roles and the construction of ignorance in a scientific controversy." In Public Understanding of Science (18), originally published online 16 September 2008, pp. 23-42.

Szerszynski, B. (1996). "On knowing what to do: environmentalism and the modern problematic." In S. Lash, B. Szerszynski and B. Wynne (Eds.), Risk, Environment \& Modernity: Towards a New Ecology. Sage Publications Ltd.: London, England. Pp. 104-37.

Szerszynski, B., S. Lash and B. Wynne (1996). "Introduction: Ecology, realism and the social sciences." In S. Lash, B. Szerszynski and B. Wynne (Eds.), Risk, Environment \& Modernity: Towards a New Ecology. Sage Publications Ltd.: London, England. Pp. 1-26.

Timura, C. T. (2001). “'Environmental conflict' and the social life of environmental security discourse.” In Anthropological Quarterly (74: 3), July 2001, pp. 10413.

von Storch, H. (2010). "Protagonists in the market of climate change knowledge." In Boykoff, M. (Ed.), The Politics of Climate Change: A Survey. Routledge: London. Pp. 62-76.

Weber, E. P. (1998). Pluralism by the Rules: Conflict and Cooperation in Environmental Regulation. Georgetown University Press: Washington, DC, United States. 
Wilkinson, I. (1999). "News media discourse and the state of public opinion on risk.” In Risk Management (1: 4), pp. 21-31.

Winnipeg Free Press. (2012). History. Retrieved from http://www.winnipegfreepress.com/history.html.

Wynne, B. (1996). "May the sheep safely graze?: A reflexive view of the expert-lay knowledge divide." In S. Lash, B. Szerszynski and B. Wynne (Eds.), Risk, Environment \& Modernity: Towards a New Ecology. Sage Publications Ltd.: London, England. Pp. 44-83.

Yeh, E. T. (2009). “Greening western China: a critical view.” In Geoforum (40), pp. 884-94. 


\section{Appendix I: List of News Articles}

\begin{tabular}{|c|c|c|c|c|}
\hline $\begin{array}{c}\text { Article } \\
\#\end{array}$ & $\begin{array}{l}\text { Date } \\
(\mathbf{2 0 1 1})\end{array}$ & Title & $\begin{array}{c}\text { Column } \\
\text { type }\end{array}$ & $\begin{array}{l}\text { Ref. } \\
\text { SLWA }\end{array}$ \\
\hline 1 & 4-Jan & Hydro facing stormy waters & & $*$ \\
\hline 2 & 5-Jan & Winter roads Warmer weather creating problems & & \\
\hline 3 & 11-Jan & Cottager fears 'public lynching' at gathering & & \\
\hline 4 & 14-Jan & Groups, citizens urging cottage-development freeze & & $*$ \\
\hline 5 & 15-Jan & $\begin{array}{l}\text { Mayors, reeves meet with province to discuss } \\
\text { flooding }\end{array}$ & & \\
\hline 6 & 16-Jan & 7 things you might have missed this week & Editorial & \\
\hline 7 & 17-Jan & Marshes need many champions & & $*$ \\
\hline 8 & 22-Jan & Have your say & $\begin{array}{l}\text { Have your } \\
\text { say }\end{array}$ & \\
\hline 9 & 22-Jan & Sewage plant project delayed & & $*$ \\
\hline 10 & 27-Jan & In brief & & \\
\hline 11 & 10-Feb & How to destroy an ancient sand beach & Editorial & \\
\hline 12 & 12-Feb & City eyes snubbing waste-treatment rules & & $*$ \\
\hline 13 & 14-Feb & Lake never sleeps under blanket of ice & Editorial & $*$ \\
\hline 14 & $15-\mathrm{Feb}$ & $\begin{array}{l}\text { Vote out waste The potential for providing } \\
\text { sufficient... }\end{array}$ & $\begin{array}{l}\text { Have your } \\
\text { say }\end{array}$ & * \\
\hline 15 & $15-\mathrm{Feb}$ & Foolish water wars & & $*$ \\
\hline 16 & 18-Feb & City to tweak lead battle & & $*$ \\
\hline 17 & 26-Feb & Selinger talks flood & & \\
\hline 18 & 27-Feb & Time to cook their GOOSE & Editorial & \\
\hline 19 & 28-Feb & Cleaner pigs & & $*$ \\
\hline 20 & 2-Mar & Cottagers can build erosion barrier & & \\
\hline 21 & 5-Mar & $\begin{array}{l}\text { Province issues a stop-work order for Victoria } \\
\text { Beach... }\end{array}$ & & \\
\hline 22 & 18-Mar & Remove rock walls at Victoria Beach: province & & \\
\hline 23 & 19-Mar & Phosphorus, algae blooms follow flooding & & $*$ \\
\hline 24 & 22-Mar & Rock wall ordered down & & \\
\hline 25 & 23-Mar & Would you drink this water? & & $*$ \\
\hline 26 & 24-Mar & $\begin{array}{l}\text { Lake Winnipeg Major flood could be disastrous: } \\
\text { Min... }\end{array}$ & & $*$ \\
\hline 27 & 29-Mar & Cottagers act to keep beachfront barrier & & \\
\hline 28 & 31-Mar & Ruling blocks removal of beach barrier & & \\
\hline 29 & 2-Apr & Losing the lake & & $*$ \\
\hline 30 & 9-Apr & $\begin{array}{l}\text { Beausejour gets OK to dump treated waste into } \\
\text { river }\end{array}$ & & \\
\hline 31 & 9-Apr & Fiery Selinger exhorts troops & & $*$ \\
\hline 32 & 20-Apr & Cottagers may be next victims & & \\
\hline 33 & 20-Apr & Liberals pledge new freshwater strategy & & \\
\hline 34 & 23-Apr & Tonnes of treated sewage to be buried in landfill & & $*$ \\
\hline 35 & 23-Apr & No end soon to water woes, minister warns & & \\
\hline 36 & 23-Apr & Dike-building focus turns to lakes & & \\
\hline
\end{tabular}




\begin{tabular}{|c|c|c|c|c|}
\hline $\begin{array}{l}\text { Article } \\
\#\end{array}$ & $\begin{array}{l}\text { Date } \\
(2011)\end{array}$ & Title & $\begin{array}{c}\text { Column } \\
\text { type }\end{array}$ & $\begin{array}{l}\text { Ref. } \\
\text { SLWA }\end{array}$ \\
\hline 37 & 28-Apr & Life's not a beach, for now & & $*$ \\
\hline 38 & 29-Apr & Hardship for people, not wildlife & & \\
\hline 39 & 30-Apr & First Nations blame feds for host of flooding woes & & \\
\hline 40 & 30-Apr & High wind, rain expected to add to flooding woes & & \\
\hline 41 & 5-May & Rivers crest in city without major flooding & & \\
\hline 42 & 18-May & Diversion unhealthy for Lake Manitoba & & \\
\hline 43 & 20-May & $\begin{array}{l}\text { Southern chiefs appeal to UN to assess Hydro } \\
\text { proj... }\end{array}$ & & \\
\hline 44 & 21-May & Water control may hurt local marshes & & \\
\hline 45 & 21-May & Welcome to soggy Manitoba & & \\
\hline 46 & 21-May & Wetlands good flood-fighters & Editorial & \\
\hline 47 & 25-May & Flood water flows to northern communities & & \\
\hline 48 & 27-May & Lake board's new head vows change & & $*$ \\
\hline 49 & 31-May & Flood channel proposed & & \\
\hline 50 & 1-Jun & Start fighting the next flood now & Editorial & \\
\hline 51 & 1-Jun & Province vows to save Lake Winnipeg & & $*$ \\
\hline 52 & 2-Jun & Premier to tackle rehab of wetlands & & $*$ \\
\hline 53 & 2-Jun & Admit mistake, save $\$ 350$ million & & $*$ \\
\hline 54 & 2-Jun & Nitrogen debate wastes time, money & & $*$ \\
\hline 55 & 3-Jun & Hogs blamed for lake woes & & $*$ \\
\hline 56 & 3-Jun & No plan to cut nitrogen from city's waste water & & $*$ \\
\hline 57 & 4-Jun & Mr Selinger sets target, lacks plan & & $*$ \\
\hline 58 & 6-Jun & Have your say & $\begin{array}{l}\text { Have your } \\
\text { say }\end{array}$ & $*$ \\
\hline 59 & 6-Jun & $\begin{array}{l}\text { Intellectual honesty in provincial election attack } \\
\text { ads }\end{array}$ & Editorial & $*$ \\
\hline 60 & 8-Jun & Have your say & $\begin{array}{l}\text { Have your } \\
\text { say }\end{array}$ & $*$ \\
\hline 61 & 10-Jun & Have your say & $\begin{array}{l}\text { Have your } \\
\text { say }\end{array}$ & * \\
\hline 62 & 11-Jun & Politics making ag sector scapegoat for lake's woes & Editorial & $*$ \\
\hline 63 & 11-Jun & It's maximum FACETIME TIME & & $*$ \\
\hline 64 & 14-Jun & City Hall Roundup & & $*$ \\
\hline 65 & 16-Jun & As a lake rises, residents recede & & \\
\hline 66 & 17-Jun & Race is on now that the session is out & & $*$ \\
\hline 67 & 18-Jun & Is it just pre-election hogwash? & Editorial & $*$ \\
\hline 68 & 24-Jun & Farmers' no-show a standard protest vote & & $*$ \\
\hline 69 & 24-Jun & Foundation leads charge to save Lake Winnipeg & & $*$ \\
\hline 70 & 24-Jun & Cottages eyed despite devastation & & \\
\hline 71 & 5-Jul & Province has plan to lower lake & & \\
\hline 72 & 8-Jul & $\begin{array}{l}\text { These David Suzuki acolytes expertly dipping } \\
\text { sophis... }\end{array}$ & & $*$ \\
\hline 73 & 9-Jul & Province conducts lake checkup & & $*$ \\
\hline 74 & 9-Jul & Residents on Lake Winnipeg shore clean up after . & & \\
\hline 75 & 15-Jul & Work on lake channel expected to start soon & & \\
\hline 76 & 16-Jul & N. Dakota diverting flood water north & & \\
\hline 77 & 16-Jul & Have your say & $\begin{array}{l}\text { Have your } \\
\text { say }\end{array}$ & \\
\hline 78 & 28-Jul & $\begin{array}{l}\text { Lake Winnipeg residents fear a repeat of fall } \\
\text { flooding }\end{array}$ & & \\
\hline
\end{tabular}




\begin{tabular}{|c|c|c|c|c|}
\hline \multicolumn{2}{|c|}{$\begin{array}{l}\text { ArticlDate } \\
\text { e \# (2011) }\end{array}$} & Title & \multirow{2}{*}{$\begin{array}{l}\text { Column } \\
\text { type }\end{array}$} & \multirow[t]{2}{*}{$\begin{array}{l}\text { Re: } \\
\text { SLWA }\end{array}$} \\
\hline 79 & 3-Aug & Have your say & & \\
\hline 80 & 5-Aug & What exactly are Selinger's 'green' priorities? & & $*$ \\
\hline 81 & 6-Aug & Letter of the Day: Cleaner than algae & $\begin{array}{l}\text { Have your } \\
\text { say }\end{array}$ & $*$ \\
\hline 82 & 6-Aug & Water acceptable for swimming at all beaches & & \\
\hline 83 & 11-Aug & Have your say & $\begin{array}{l}\text { Have your } \\
\text { say }\end{array}$ & \\
\hline 84 & 12-Aug & Duo prepares to swim across Lake Winnipeg & & \\
\hline 85 & 12-Aug & Flooding takes bloom off algae growth & & $*$ \\
\hline 86 & 18-Aug & Have your say & $\begin{array}{l}\text { Have your } \\
\text { say }\end{array}$ & $*$ \\
\hline 87 & 19-Aug & Have your say & $\begin{array}{l}\text { Have your } \\
\text { say }\end{array}$ & \\
\hline 88 & 25-Aug & Have your say & $\begin{array}{l}\text { Have your } \\
\text { say }\end{array}$ & \\
\hline 89 & 25-Aug & Wind alert worries cottagers & & \\
\hline 90 & 27-Aug & The drain on the plain & Editorial & \\
\hline 91 & 27-Aug & Saving Lake Winnipeg - A letter of concern & $\begin{array}{l}\text { Advertise- } \\
\text { ment }\end{array}$ & $*$ \\
\hline 92 & 29-Aug & Farmers use dams to keep water on land & & \\
\hline 93 & 30-Aug & Farmers have new way to fix Lake Winnipeg & & $*$ \\
\hline 94 & 31-Aug & Swollen lake slowly killing wetland & & $*$ \\
\hline 95 & 1-Sep & Economic plan includes cash for back lanes & & $*$ \\
\hline 96 & 1-Sep & Ideas, no price tags on floods & & \\
\hline 97 & 2-Sep & Answer $\$ 400-\mathrm{M}$ question & & $*$ \\
\hline 98 & 2-Sep & Converting cattails to fuel could save vital marsh & & * \\
\hline 99 & 3-Sep & Vote Manitoba & & $*$ \\
\hline 100 & 3-Sep & What Hugh MUST DO & & $*$ \\
\hline 101 & 3-Sep & Praying for a real election & Editorial & $*$ \\
\hline 102 & 9-Sep & Ban on expansion hog-ties us: farmers & & $*$ \\
\hline 103 & 10-Sep & Flood evacuees feel forgotten & & \\
\hline 104 & 15-Sep & Letter of the day: Something smells watery & $\begin{array}{l}\text { Have your } \\
\text { say }\end{array}$ & $*$ \\
\hline 105 & 17-Sep & Push for province's clean power & & \\
\hline 106 & 19-Sep & Have your say & $\begin{array}{l}\text { Have your } \\
\text { say }\end{array}$ & $*$ \\
\hline 107 & 23-Sep & Wetlands key for Tory plan for lake & & \\
\hline 108 & 27-Sep & Have your say & $\begin{array}{l}\text { Have your } \\
\text { say }\end{array}$ & $*$ \\
\hline 109 & 28-Sep & Seats are must-wins for Conservatives & & \\
\hline 110 & 1-Oct & $\begin{array}{l}\text { Liberals crime and justice expand and improve } \\
\text { inner... }\end{array}$ & & \\
\hline 111 & 15 -Oct & Community 'shaken' after Hydro flooding & & \\
\hline 112 & $17-$-Oct & Lakefront communities brace for gales & & \\
\hline 113 & 17-Oct & High winds threaten Lake Winnipeg shoreline & & \\
\hline 114 & 25 -Oct & Interpretive trail for wetlands & & \\
\hline 115 & 3-Nov & $\begin{array}{l}\text { Problem with bacteria hampers waste-treatment } \\
\text { plant }\end{array}$ & & \\
\hline 116 & 4-Nov & Anger flows over slow info & & \\
\hline
\end{tabular}




\begin{tabular}{|c|c|c|c|c|}
\hline $\begin{array}{l}\text { Articl } \\
\text { e \# }\end{array}$ & $\begin{array}{l}\text { Date } \\
\text { (2011) }\end{array}$ & Title & $\begin{array}{l}\text { Column } \\
\text { type }\end{array}$ & $\begin{array}{c}\text { Re: } \\
\text { SLWA }\end{array}$ \\
\hline 117 & 4-Nov & In the sewer & Editorial & \\
\hline 118 & 5-Nov & Engineers hope to kill bad bacteria & & \\
\hline 119 & 5-Nov & Hearings upcoming on Hydro control of lake level & & \\
\hline 120 & 6-Nov & A CRAPPY situation & & \\
\hline 121 & 7-Nov & Have your say & $\begin{array}{l}\text { Have your } \\
\text { say }\end{array}$ & \\
\hline 122 & 7-Nov & Research on lake overdue & & $*$ \\
\hline 123 & 8-Nov & Have your say & $\begin{array}{l}\text { Have your } \\
\text { say }\end{array}$ & $*$ \\
\hline 124 & 9-Nov & The pollution solution explained & & $*$ \\
\hline 125 & 14-Nov & Have your say & $\begin{array}{l}\text { Have your } \\
\text { say }\end{array}$ & $*$ \\
\hline 126 & 15-Nov & Outflow reduced from Lake Winnipeg & & \\
\hline 127 & 22-Nov & Have your say & $\begin{array}{l}\text { Have your } \\
\text { say }\end{array}$ & $*$ \\
\hline 128 & 24-Nov & Treatment plant among worst & & $*$ \\
\hline 129 & 28-Nov & Have your say & $\begin{array}{l}\text { Have your } \\
\text { say }\end{array}$ & $*$ \\
\hline 130 & 22-Dec & City gets down to nitty-gritty on sewage & & $*$ \\
\hline
\end{tabular}


Appendix II: "Saving Lake Winnipeg: A Letter of Concern" Advertisement 


\section{Saving Lake Winnipeg}

\section{-A letter of concern from the business community}
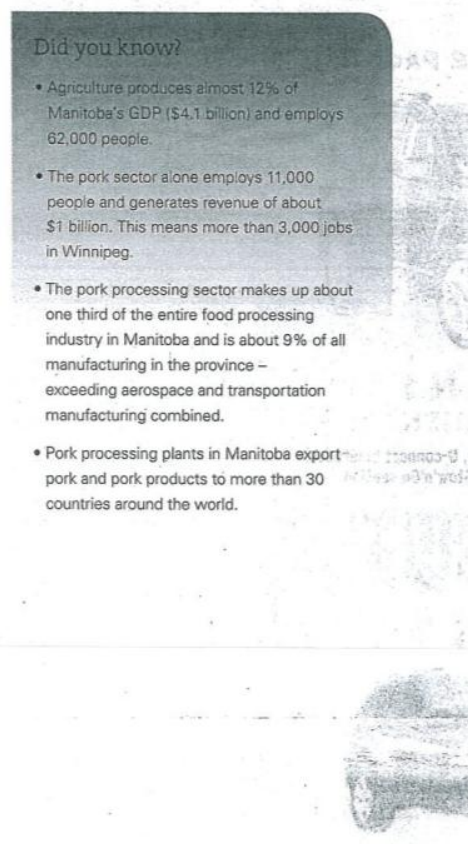

To the Citizens of Manitoba,

Did you know the provincial government recently passed legislation banning all new hog barns. and expansions in every corner of Manitoba, no matter how small the farm?

The government claimed to pass this legislation to reduce phosphorus contamination in Lake Winnipeg. It was done without any consultation with hog producers and other stakeholders, even though wo roprosent thousas ch of

The Lake Winnipeg Stewardship Board determined the following list of phosphorus contributors.

Here are the facts:

- $53 \%$ from outside the province (including the US):

- $17 \%$ from natural and undefined sources (e.g. septic fields);

- $15 \%$ from agriculture lof which hog production contributes less than $1.5 \%$ l:

- $9 \%$ from municipal wastewater; and

- $6 \%$ from the atmosphere.

As business leaders who represent many employers in the province, we believe banning or severely restricting one sector is the wrong approach to solve the problem.

One of the principal cures for the lake is better water management, as more than half the One of the principa curos for the lake is bettor water managemont, as moset in hat the - phosphorus is due to spring runoff. Better water management will also assist in drought years

We ask Manitobans to support us in urging the government to work co-operatively with the We ask Manitobans to support us in urging the government to work co-operatively with the problems, instead of penalizing the farmers who grow our food.
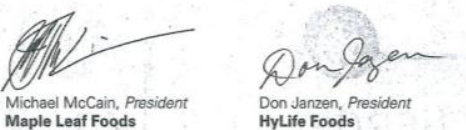

B C
Dr. Brad Chappell, DVM
Swine Health Professionals Ltd.

fota $-\frac{1}{8}$

Graham Starmer, President
Manitoba Chambers

of Commerce

Don Janzen, President
HyLife Foods

Some Funk

That Mymach Karl Kynoch, Chairman,
Manitoba Pork Council Manitoba Pork Council

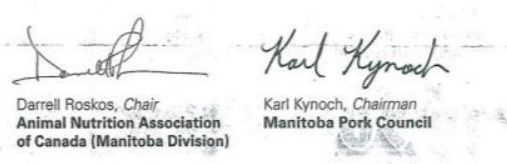

forter

Steve Brandt
Steve's Livestock Transport
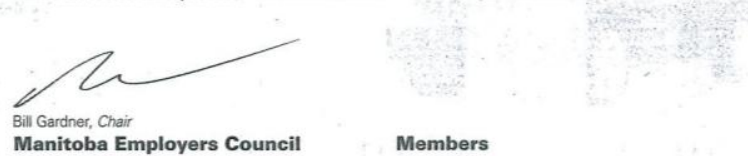

Members

\section{Manitoba Employers Council}

The Manitoba Employers Council (MEC)

established in 1980, is the largest

collective of individual employers and employer associations in Manitoba. MEC represents the interests of

Manitoba employers in matters felating

to employment, including: labour

relations, human resource management,

employment standards, and workers

compensation and workplace safety

and health.
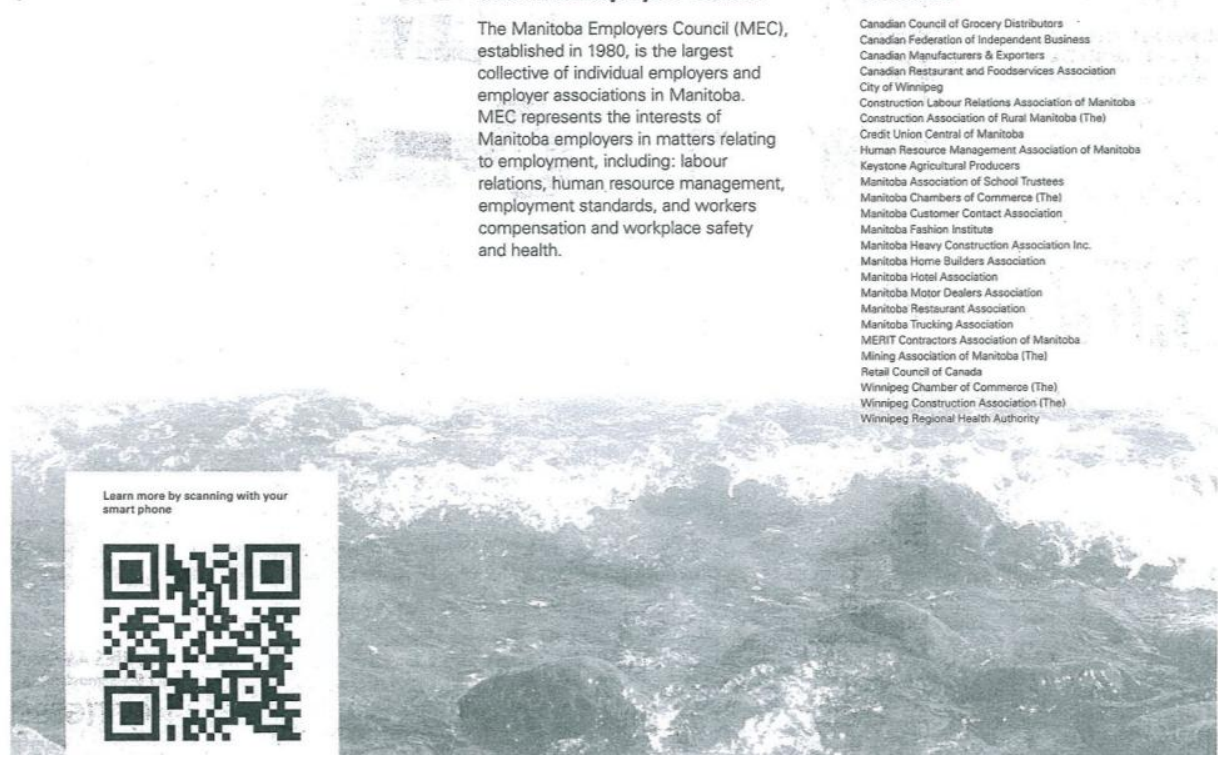
Text from the "Saving Lake Winnipeg - A letter of concern from the business community" advertisement, published in the Winnipeg Free Press on 27 August, 2011

\section{Saving Lake Winnipeg}

\section{- A letter of concern from the business community}

To the Citizens of Manitoba,

Did you know the provincial government recently passed legislation banning all new hog barns and expansions in every corner of Manitoba, no matter how small the farm?

The government claimed to pass the legislation to reduce phosphorus contamination in Lake Winnipeg. It was done without any consultation with hog producers and other stakeholders, even though we represent thousands of farms and families across our province. This simplistic ban puts thousands of jobs at risk, without dealing with the real problem.

The Lake Winnipeg Stewardship Board determined the following list of phosphorus contributions.

\section{Here are the facts:}

- $53 \%$ from outside the province (including the US);

- $17 \%$ form natural and undefined sources (e.g. septic fields);

- $15 \%$ from agriculture (of which hog production contributes less than 1.5\%);

- $9 \%$ from municipal wastewater; and

- $6 \%$ from the atmosphere.

As business leaders who represent many employers in the province, we believe banning or severely restricting one sector is the wrong approach to solve the problem. 
One of the principal [sic] cures for the lake is better waste management, as more than half the phosphorus is due to spring runoff. Better water management will also assist in drought years and help reduce flooding, which we have seen wreak havoc in much of Manitoba this year.

We ask Manitobans to support us in urging the government to work co-operatively with the farm and business communities as well as other stakeholders to help solve Lake Winnipeg's problems, instead of penalizing the farmers who grow our food.

[text box on left-hand side]

Did you know?

- Agriculture produces almost 12\% of Manitoba's GDP (\$4.1 billion) and employs 62,000 people.

- The pork sector alone employs 11,000 people and generates revenue of about $\$ 1$ billion. This means more than 3,000 jobs in Winnipeg.

- The pork processing sector makes up about one third of the entire food processing industry in Manitoba and is about 9\% of all manufacturing in the province - exceeding aerospace and transportation manufacturing combined.

- Pork processing plants in Manitoba export pork and pork products to more than 30 countries around the world.

[signed by the following]

Michael McCain, President Don Janzen, President Dr. Brad Chappell, DVM

Maple Leaf Foods HyLife Foods Swine Health Professionals

Ltd.

Graham Starmer, President Darrell Roskos, Chair Karl Kynoch, Chairman

Manitoba Chambers Animal Nutrition Manitoba Pork Council

Of Commerce Association of Canada

(Manitoba Division) 
Lorne Funk

Funk's Livestock

Transport Ltd.

Bill Gardner, Chair

Manitoba Employers Council
Ron Friesen,

Vice-President

East-Man Feeds
Steve Brandt

Steve's Livestock Transport

The Manitoba Employers Council (MEC), established in 1980, is the largest collective of individual employers and employer associations in Manitoba. MEC represents the interests of Manitoba employers in matters relating to employment, including: labour relations, human resource management, employment standards, and workers compensation and workplace safety and health.

\section{Members}

Canadian Council of Grocery Distributors

Canadian Federation of Independent Business

Canadian Manufacturers \& Exporters

Canadian Restaurant and Foodservices Association

City of Winnipeg

Construction Labour Relations Association of Manitoba

Construction Association of Rural Manitoba (The)

Credit Union Central of Manitoba

Human Resource Management Association of Manitoba

Keystone Agricultural Producers

Manitoba Association of School Trustees

Manitoba Chambers of Commerce (The)

Manitoba Customer Contact Association

Manitoba Fashion Institute

Manitoba Heavy Construction Association Inc.

Manitoba Home Builders Association

Manitoba Hotel Association 
Manitoba Motor Dealers Association

Manitoba Restaurant Association

Manitoba Trucking Association

MERIT Contractors Association of Manitoba

Mining Association of Manitoba (The)

Retail Council of Canada

Winnipeg Chamber of Commerce (The)

Winnipeg Construction Association (The)

Winnipeg Regional Health Authority

[graphic across the bottom: a picture of Lake Winnipeg] 